\title{
Efficiency of serum protein removal from skim milk with ceramic and polymeric membranes at $50^{\circ} \mathrm{C}^{1}$
}

\author{
J. Zulewska, ${ }^{*}$ M. Newbold, $\dagger$ and D. M. Barbano ${ }^{2}$ \\ *Faculty of Food Sciences, University of Warmia and Mazury, Olsztyn, Poland \\ †Cornell University Department of Food Science, Northeast Dairy Foods Research Center, Ithaca, NY 14853
}

\begin{abstract}
Raw milk $(2,710 \mathrm{~kg})$ was separated at $4^{\circ} \mathrm{C}$, the skim milk was pasteurized $\left(72^{\circ} \mathrm{C}, 16 \mathrm{~s}\right)$, split into 3 batches, and microfiltered using pilot-scale ceramic uniform transmembrane pressure (UTP; Membralox model EP1940GL0.1 $\mu$ A, $0.1 \mu \mathrm{m}$ alumina, Pall Corp., East Hills, NY), ceramic graded permeability (GP; Membralox model EP1940GL0.1 $\mu$ AGP1020, $0.1 \mu \mathrm{m}$ alumina, Pall Corp.), and polymeric spiral-wound (SW; model FG7838-OS0x-S, $0.3 \mu \mathrm{m}$ polyvinylidene fluoride, Parker-Hannifin, Process Advanced Filtration Division, Tell City, IN) membranes. There were differences in flux among ceramic UTP, ceramic GP, and polymeric SW microfiltration membranes $(54.08,71.79$, and 16.21 $\mathrm{kg} / \mathrm{m}^{2}$ per hour, respectively) when processing skim milk at $50^{\circ} \mathrm{C}$ in a continuous bleed-and-feed $3 \times$ process. These differences in flux among the membranes would influence the amount of membrane surface area required to process a given volume of milk in a given time. Further work is needed to determine if these differences in flux are maintained over longer processing times. The true protein contents of the microfiltration permeates from UTP and GP membranes were higher than from SW membranes $(0.57,0.56$, and $0.38 \%$, respectively). Sodium-dodecyl-sulfate-PAGE gels for permeates revealed a higher casein proportion in GP and SW permeate than in UTP permeate, with the highest passage of casein through the GP membrane under the operational conditions used in this study. The slight cloudiness of the permeates produced using the GP and SW systems may have been due to the presence of a small amount of casein, which may present an obstacle in their use in applications when clarity is an important functional characteristic. More $\beta$-lactoglobulin passed through the ceramic membranes than through the poly-
\end{abstract}

\footnotetext{
Received September 28, 2008.

Accepted November 18, 2008

${ }^{1}$ Use of names, names of ingredients, and identification of specific models of equipment is for scientific clarity and does not constitute any endorsement of product by authors, University of Warmia and Mazury, Cornell University, or the Northeast Dairy Foods Research Center.

${ }^{2}$ Corresponding author: dmb37@cornell.edu
}

meric membrane. The efficiency of removal of serum proteins in a continuous bleed-and-feed $3 \times$ process at $50^{\circ} \mathrm{C}$ was $64.40 \%$ for UTP, $61.04 \%$ for GP, and $38.62 \%$ for SW microfiltration membranes. The SW polymeric membranes had a much higher rejection of serum proteins than did the ceramic membranes, consistent with the sodium-dodecyl-sulfate PAGE data. Multiple stages and diafiltration would be required to produce a 60 to $65 \%$ serum protein reduced micellar casein concentrate with SW membranes, whereas only one stage would be needed for the ceramic membranes used in this study.

Key words: microfiltration, flux, serum protein, protein fractionation

\section{INTRODUCTION}

Microfiltration (MF) is a pressure-driven separation process using membranes with a pore-size diameter ranging from 20 to $0.1 \mu \mathrm{m}$ (Maubois, 2002). The 2 most common applications of MF in the dairy industry (Saboya and Maubois, 2000) are removal of bacteria and spores from skim milk and separation of micellar casein from serum proteins (SP). Separation of micellar casein from SP in skim milk relies on the difference in size between casein micelles $(0.2 \mu \mathrm{m})$ and SP $(0.0036$ $\mu \mathrm{m})$ when using ceramic membranes with a pore-size diameter around $0.1 \mu \mathrm{m}$. The separation of casein and SP by $0.1-\mu \mathrm{m}$ ceramic membranes is accomplished by a combination of the selectivity of the membrane (Brans et al., 2004) and the lift on particles in the feed stream created by very high shear turbulent flow (Altmann and Ripperger, 1997).

Separation of casein and SP with spiral-wound polymeric membranes depends more on the combination of properties of the membrane and the fouling layer (Riedl et al., 1998). Microfiltration produces a permeate with a composition similar to that of sweet whey with the main components being $\beta-\mathrm{LG}, \alpha-\mathrm{LA}$, lactose, minerals, and NPN. Microfiltration permeate is clear, sterile, free of phage, and is an excellent starting material for production of SP concentrates or isolates (Saboya and Maubois, 2000). The casein obtained by MF of skim milk shows many interesting properties especially for 
the cheese industry (Caron et al., 1997; Saint-Gelais et al., 1998; Neocleous et al., 2002a, b).

Most ultrafiltration in the dairy industry uses polymeric membranes, which cost less than ceramic membranes and require less energy but have relatively low chemical stability (Jost and Jelen, 1997) and a shorter life compared with ceramic membranes (Cheryan, 1998). Ceramic membranes are very resistant to extreme chemical and physical conditions and can withstand a $\mathrm{pH}$ range from 0.5 to 13.5 and temperatures $>100^{\circ} \mathrm{C}$ (Baruah et al., 2006). However, there is a need to change temperature gradually $\left(<10^{\circ} \mathrm{C}\right.$ per min $)$ with ceramic membranes to avoid cracking of the membrane.

Brans et al. (2004) has reviewed the mechanism of fouling of MF membranes. To overcome a rapid fouling of MF membranes when processing skim milk caused by large transmembrane pressure, Sandblom (1978) developed a uniform transmembrane pressure (UTP) system in which the MF permeate circulates in a loop parallel to the direction of the retentate flow. The specific conditions (flow) are chosen to ensure low and uniform transmembrane pressure from the retentate inlet to outlet end of the membrane. In the method patented by Alfa Laval, the permeate side of the membrane is filled with polymeric beads (Holm et al., 1990), which aids in control of transmembrane pressure to reduce fouling. A ceramic UTP MF system consists of a feed pump and 2 recirculation pumps, 1 for retentate and 1 for permeate. Recent attempts to achieve the benefits of UTP in alternative ways and reduce electrical operating cost have resulted in the development of graded permeability (GP) ceramic membranes (e.g., Membralox GP, Pall Corporation, East Hills, NY). The GP membranes have the uniform thickness and porosity of the selective membrane layer and a difference in permeability built into the ceramic support structure, with the support structure providing more resistance to permeate flow at the retentate inlet end of the membrane and less resistance to flow at the retentate outlet end of the membrane (Garcera and Toujas, 2002). In addition, restriction of the permeate removal rate controls pressure and the rate of permeate flow throughout the length of a GP membrane. The GP approach claims to maintain a constant and uniform flux along all parts of the membrane, while eliminating the need for a permeate recirculation pump and the associated electrical costs. Another approach used to overcome the higher operational cost of the permeate recirculation loop of UTP systems while controlling fouling uses a continuous gradient in the thickness of MF membrane selective layer along the membrane length (Saboya and Maubois, 2000) and a uniform porosity of the ceramic support structure. The commercial name of the system patented by Grangeon et al. (2002) is "Isoflux" and it is manufactured by TAMI Industries (Nyones, France). Ceramic membrane systems are typically in multichannel configuration with either cylindrical channels or various cross-section forms (Saboya and Maubois, 2000) to increase amount of the filtration area per module.

Recently, spiral-wound polymeric MF membranes have become available and provide a large amount of membrane surface area per module at a lower cost per square meter than ceramic membranes, but with a more frequent need for replacement. Zeman (1996) listed 17 polymers commonly used in commercial MF and UF applications. The physical and chemical conditions used during processing, as well as the characteristics of the feed material, determine to a large extent the separation properties of polymeric membranes. Approaches used to minimize fouling of polymeric spiral-wound (SW) membranes include the use of polymeric spacer materials of various thicknesses in the retentate flow path to create turbulent flow. Spiral-wound membranes use much lower retentate side pressures than ceramic membranes to avoid compaction of the membrane and to keep transmembrane pressure low. In contrast to the use of back pressure on the permeate side for operation of ceramic membranes, back pressure from the permeate side in a SW polymeric membrane system cannot be used because it will damage the membrane. The polymeric membrane formation technology and types of polymer blends must produce a membrane with reproducible quality and performance (Zeman, 1996).

The type of MF membrane used for processing of skim milk may affect the efficiency of transmission of SP, protein composition of the retentate and permeate, the level of residual casein in the permeate, and the cost of the process. Differences in composition may influence the functional and sensory properties of MF retentate and permeate products. The differences in efficiency of SP removal ( $\mathrm{kg}$ of SP removed $/ \mathrm{m}^{2}$ per hour) will also influence the amount of membrane surface area required to accomplish the process and to obtain retentate and permeate with the desired composition. A higher rejection of SP by an MF membrane will require additional diafiltration and membrane surface area to achieve a given percentage of SP removal and will increase processing cost. The only data available in the literature for efficiency of removal of SP from skim milk is for a UTP ceramic membrane system (Nelson and Barbano, 2005), which shows that in a 3-stage continuous bleed-and-feed process with a $3 \times$ concentration factor, it was possible to remove $95 \pm 1.1 \%$ of SP from skim milk at $50^{\circ} \mathrm{C}$. No data are available in the literature on the efficiency of removal of SP from skim milk by using polymeric membranes or graded permeability membranes. The objective of our research was to compare the flux and SP removal for 3 different MF 
membrane systems: ceramic UTP membranes, ceramic GP membranes, and polymeric SW membranes for a continuous bleed-and-feed $3 \times$ process when processing skim milk at $50^{\circ} \mathrm{C}$.

\section{MATERIALS AND METHODS}

\section{Experimental Design and Statistical Analysis}

One lot of bovine milk (approximately 2,710 kg) was separated in the Cornell University dairy plant at $4^{\circ} \mathrm{C}$ using a model 590 Air Tight Centrifuge (DeLaval Co., Chicago, IL). The raw skim milk was pasteurized with a plate heat exchanger (3 sections: regeneration, heating, and cooling, model 080-S, AGC Engineering, Manassas, VA) at $72^{\circ} \mathrm{C}$ and a holding time of $16 \mathrm{~s}$. The milk was cooled to $4^{\circ} \mathrm{C}$ and stored at $\leq 4^{\circ} \mathrm{C}$ until processing. The milk was split into 3 batches and microfiltered using a pilot-scale ceramic UTP, ceramic GP, and polymeric SW MF system. For all membranes, a bleed-and-feed process was used to continuously produce a $3 \times \mathrm{MF}$ retentate and $\mathrm{MF}$ permeate at $50^{\circ} \mathrm{C}$. The processing for each replicate was done over a 3 -d period running one MF system per day. The experiment was replicated 3 times and the order of processing with different MF systems was rotated from one replicate to the next so that the average time of milk storage before MF by each type of membrane system was the same for the 3 replicates.

To determine if there were significant differences among different MF systems (UTP, GP, and SW), all data were analyzed by ANOVA using PROC GLM of SAS (SAS version 8.02, 1999-2001, SAS Institute Inc., Cary, NC). The GLM for composition, flux, and SP removal was dependent variable $=$ treatment $(\mathrm{UTP}$, GP, or SW) + replicate + error. To determine if flux changed with the time of processing run after the first 30 min of running, the model was dependent variable $=$ time + replicate + time $\times$ replicate + error, with time as a continuous variable in the model. The flux measurement for SW membrane was taken every 10 min during the processing. Time was treated as a continuous variable in the split-plot ANOVA models. Distortion of the ANOVA by multicollinearity in the model was minimized by centering the time of running using a mathematical transformation (Glantz and Slinker, 2001). Time was transformed as follows: time $=$ running time $-[$ (last time - first time)/2]. This transformation made the data set orthogonal with respect to time.

\section{UTP System}

A pilot-scale UTP MF system (Tetra Alcross MFS7, TetraPak Filtration Systems, Aarhus, Denmark)

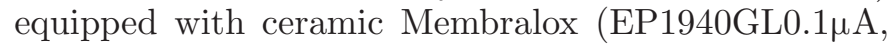

alumina, Pall Corp.) membranes (pore diameter of 0.1 $\mu \mathrm{m}$; surface area of $1.7 \mathrm{~m}^{2}$ ) was used. The membranes in a tubular single stainless steel module consisted of 7 ceramic tubes, 19 channels each with a 4-mm channel diameter. The inside of the permeate section of the stainless steel module was filled with polymeric beads ( 3.72 to $3.78 \mathrm{~mm}$ in diameter) to reduce dead volume on the permeate side of the system and to act as a buffer for pressure changes. The UTP MF system consisted of a feed pump (type LKH 10/110 SSS 1.75 $\mathrm{kW}$ ), a retentate recirculation pump (type LKH 20/125 SSS $6.3 \mathrm{~kW}$ ), and a permeate recirculation pump (type LKH 10/130 SSS $2.5 \mathrm{~kW}$ ), all from Alfa Laval (Kansas City, MO). The membranes were $1.02 \mathrm{~m}$ long and were mounted vertically in the MF system. The flow of the retentate and permeate was co-current, with both flowing from the top to the bottom of the vertically mounted membrane.

Immediately before the processing, the MF system was cleaned. The storage solution $(0.55 \% \mathrm{vol} / \mathrm{vol} \mathrm{solu}-$ tion of nitric acid) was flushed out of the system with room temperature reverse osmosis (RO) water until the $\mathrm{pH}$ was neutral. The MF flow system was heated with $\mathrm{RO}$ water to $80^{\circ} \mathrm{C}$ and then Ultrasil 25 (Ecolab Inc., Food and Beverage Division, St Paul, MN) liquid alkaline membrane cleaner $(1.95 \% \mathrm{vol} / \mathrm{vol})$ was added to the water to reach $\mathrm{pH} 11$. The alkaline solution was recirculated for $25 \mathrm{~min}$ at a permeate flow of approximately $1,000 \mathrm{~L} / \mathrm{h}$, the retentate flow at approximately 160 to $180 \mathrm{~L} / \mathrm{h}$, and all pumps on. After cleaning, the membrane system was slowly $\left(<10^{\circ} \mathrm{C}\right.$ per min) cooled to $50^{\circ} \mathrm{C}$ with the tubular heat exchanger in the recirculation loop of the unit. The MF system was flushed with room temperature $\mathrm{RO}$ water until a neutral $\mathrm{pH}$ was reached. The membrane was flushed with $50^{\circ} \mathrm{C} \mathrm{RO}$ water and the initial clean water flux was determined. The following conditions were applied during the initial water flux measurement: the retentate outlet valve was closed, the permeate outlet valve was fully open, and only the feed pump running.

Because the membrane was mounted vertically, the inlet and outlet gauge pressures had to be corrected for the difference due to the weight of the vertical column of liquid. The correction was measured as follows: with $50^{\circ} \mathrm{C} \mathrm{RO}$ water in the system and only the feed pump turned on, the retentate and permeate outlet valves were closed. The retentate pressure inlet $\left(\mathbf{R p}_{\mathbf{i}}\right)$, the permeate pressure inlet $\left(\mathbf{P p}_{\mathbf{i}}\right)$, the retentate pressure outlet $\left(\mathbf{R} \mathbf{p}_{\mathbf{o}}\right)$, and the permeate pressure outlet $\left(\mathbf{P p}_{\mathbf{o}}\right)$ were measured under these conditions. The correction factor was calculated for each gauge pressure as follows: the $R p_{i}$ gauge pressure correction was $\mathrm{Pp}_{\mathrm{o}}$ minus $\mathrm{Rp}_{\mathrm{i}}$; the $\mathrm{Rp}_{\mathrm{o}}$ gauge pressure correction was $\mathrm{Pp}_{\mathrm{o}}$ minus $\mathrm{Rp}_{\mathrm{o}}$; the $\mathrm{Pp}_{\mathrm{i}}$ gauge pressure correction was $\mathrm{Pp}_{\mathrm{o}}$ minus 
$\mathrm{Pp}_{\mathrm{i}}$; and the $\mathrm{Pp}_{\mathrm{o}}$ gauge pressure correction was zero. Next, retentate and permeate recirculation pumps were turned on and the retentate bleed flow was set to 45 $\mathrm{L} / \mathrm{h}$ and the permeate bleed flow was set to $90 \mathrm{~L} / \mathrm{h}$. The elevation corrected inlet and outlet pressures were measured and the transmembrane pressure at inlet $\left(\mathbf{T M P}_{\mathbf{i}}\right)$ and outlet $\left(\mathbf{T M P} \mathbf{P}_{\mathbf{o}}\right)$ were calculated. The goal was to have $\Delta \mathrm{P}\left(\Delta \mathrm{P}=\mathrm{TMP}_{\mathrm{i}}-\mathrm{TMP}_{\mathrm{o}}\right)$ of $25 \pm 3 \mathrm{kPa}$. There was a diaphragm valve in the permeate recirculation loop that was used to adjust the recirculation flow rate on the permeate side of the membrane. The permeate recirculation flow rate was adjusted with the diaphragm valve until $\Delta \mathrm{P}$ was $25 \pm 3 \mathrm{kPa}$.

Skim milk (about $763 \mathrm{~kg}$ ) was concentrated 3-fold at $50^{\circ} \mathrm{C}$ using a pilot-scale UTP MF system described above. The system was started on $50^{\circ} \mathrm{C} \mathrm{RO}$ water and there was a transition from water to milk with all 3 pumps running. To push $50^{\circ} \mathrm{C}$ water out of the system with milk at the beginning of the process, about $16 \mathrm{~kg}$ of retentate and $32 \mathrm{~kg}$ of permeate were collected, the weights were recorded, and the retentate (mostly water) was discarded while the permeate was collected. Next, the retentate and permeate were collected continuously and cooled to $4^{\circ} \mathrm{C}$ as they were collected. At a concentration factor of 3 , the retentate and permeate removal rates were 45 and $90 \mathrm{~L} / \mathrm{h}$, respectively. If $\Delta$ Pwas not 25 $\pm 3 \mathrm{kPa}$ after switching from water to milk, then the permeate recirculation diaphragm valve was adjusted while processing skim milk to achieve and maintain this $\Delta \mathrm{P}$ between the outlet and inlet end of the membrane. Typical $\mathrm{Rp}_{\mathrm{i}}$ and $\mathrm{Pp}_{\mathrm{i}}$ were 420.7 and $388.9 \mathrm{kPa}$, respectively, and typical $\mathrm{Rp}_{o}$ and $\mathrm{Pp}_{\mathrm{o}}$ were about 230.1 and $217.7 \mathrm{kPa}$, respectively. The flux $\left(\mathrm{kg} / \mathrm{m}^{2}\right.$ per hour) was determined every $15 \mathrm{~min}$, and samples of permeate and the retentate were taken for analysis using an infrared spectrophotometer (Lactoscope FTIR, Delta Instruments, Drachten, the Netherlands) to monitor the composition of the retentate and permeate for process control. At the end of the MF run, all retentate and all permeate from the processing run were mixed and each was sampled. The average total time of milk processing was about $344 \mathrm{~min}$.

Immediately after processing, $50^{\circ} \mathrm{C} \mathrm{RO}$ water (about 100 to $130 \mathrm{~L}$ ) was flushed through the system with all pumps on. The retentate and permeate removal rates were set at approximately 160 and $120 \mathrm{~L} / \mathrm{h}$, respectively. The MF system was flushed until no milk was visible in the flush water on the retentate side. When the water flush was complete, the fouled membrane water flux was determined (retentate outlet valve closed, permeate outlet valve completely open, only the feed pump on with the temperature maintained at $50^{\circ} \mathrm{C}$ ). Typically, the fouled membrane flux was about $46 \%$ of the clean membrane water flux $\left(1,065\right.$ vs. $491 \mathrm{~kg} / \mathrm{m}^{2}$ per hour). Next, the MF flow system was heated with RO water to $80^{\circ} \mathrm{C}$. Ultrasil 25 liquid alkaline membrane cleaner (Ecolab Inc.) was added $(1.95 \% \mathrm{vol} / \mathrm{vol})$ to the water to reach $\mathrm{pH}$ 11. The solution was recirculated for $25 \mathrm{~min}$, with permeate and retentate exit flows at approximately $1,000 \mathrm{~L} / \mathrm{h}$ and 160 to $180 \mathrm{~L} / \mathrm{h}$ with all pumps on. After the cleaning, the membrane system was slowly $\left(<10^{\circ} \mathrm{C}\right.$ per min) cooled to $50^{\circ} \mathrm{C}$ with the heat exchanger on the unit. The membrane was then flushed with room temperature RO water until neutral $\mathrm{pH}$ was reached. The MF flow system was heated to $50^{\circ} \mathrm{C}$ by flushing with $50^{\circ} \mathrm{C} \mathrm{RO}$ water and the postrun clean water flux was determined. During the flux determination the retentate outlet valve was closed, the permeate outlet valve was fully open with only the feed pump on, and the temperature was maintained at $50^{\circ} \mathrm{C}$. The post-run clean water flux was very close to the pre-run clean water flux (i.e., about 1,050 to $1,070 \mathrm{~L} / \mathrm{m}^{2}$ per hour). After determination of the clean water flux, a solution of nitric acid $(0.55 \% \mathrm{vol} / \mathrm{vol})$ was recirculated through the membrane at $50^{\circ} \mathrm{C}$ for $10 \mathrm{~min}$. Permeate and retentate outlet flows were approximately $1,000 \mathrm{~L} / \mathrm{h}$ and 160 to $180 \mathrm{~L} / \mathrm{h}$, respectively. After 10 min of the nitric acid solution recirculation, permeate and retentate outlet valves were closed and the pumps turned off. The membrane was stored in $0.55 \%$ nitric acid solution.

\section{GP System}

Pasteurized skim milk (approximately $780 \mathrm{~kg}$ ) was warmed to $50^{\circ} \mathrm{C}$ using a plate heat exchanger and microfiltered with a GP MF system (Tetra Alcross MFS-7, TetraPak Filtration Systems) equipped with $0.1-\mu \mathrm{m}$ nominal pore diameter ceramic Membralox

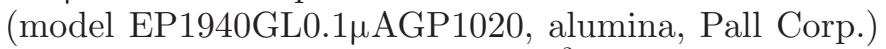
membranes (surface area of $1.7 \mathrm{~m}^{2}$, membrane length of $1.02 \mathrm{~m}$ ). The membranes had a tubular configuration with 7 tubes, 19 channels each with a 4-mm channel diameter, in one stainless steel module that was mounted vertically in the system. No beads were used to reduce the dead volume on the permeate side of the GP membrane. The pumps and piping were the same as in the UTP process, except that the permeate recirculation pump and associated piping were removed from the system. Permeate was removed at the top of the vertical membrane module with a back pressure applied. The GP MF system used only a feed pump and retentate recirculation pump. The permeate pressure at the lower end of the membrane was not measured directly and was calculated by adding $13.79 \mathrm{kPa}$ to the permeate pressure at the upper end of the membrane to correct for the elevation difference $(102 \mathrm{~cm})$ and weight of the column of liquid. 
The short cleaning at start-up was the same cleaning procedure as applied to UTP membranes. After the initial cleaning, both the feed pump and retentate recirculation pump were turned on with $50^{\circ} \mathrm{C} \mathrm{RO}$ water running through the system. To minimize the fouling of the membrane when switching from water to milk, the permeate exit valve was closed. The intake for the feed pump was switched from water to milk and about 16 $\mathrm{kg}$ of retentate (mostly water) was collected, the weight was recorded, and the liquid was discarded. During that time the retentate removal flow was kept at 90 L/h. Next, the permeate valve was quickly opened to reach the permeate removal flow of $180 \mathrm{~L} / \mathrm{h}$, for $3 \times$ concentration factor. These removal flows were chosen at start-up to keep the $\mathrm{Pp}_{\mathrm{o}}$ lower than $\mathrm{Rp}_{\mathrm{o}}$. If the $\mathrm{Pp}_{\mathrm{o}}$ at the lower end of the vertical membrane is higher than the $\mathrm{Rp}_{\mathrm{o}}$ at that same location, then permeate will flow through the membrane too fast at the top of the membrane and will be flowing backward (from the permeate side back into the retentate side) through the membrane at the lower end of the vertical membrane. This type of reverse flow has been called Starling flow (Heath et al., 1990). When this happens, the membrane fouls more quickly at the top (retentate inlet) end of the membrane. As the membrane began to foul at the beginning of the processing run, the removal rates were reduced to 60 and $120 \mathrm{~L} / \mathrm{h}$ for retentate and permeate (during the first $30 \mathrm{~min}$ ), respectively, and it was possible to achieve the $\mathrm{Pp}_{\mathrm{o}}$ lower than $\mathrm{Rp}_{\mathrm{o}}$ at the retentate exit end of the membrane. As the $\mathrm{Pp}_{\mathrm{o}}$ decreased, retentate and permeate removal flows were adjusted to maintain a $3 \times$ concentration factor using a 60 and $120 \mathrm{~L} / \mathrm{h}$ removal rate for retentate and permeate, respectively. These removal rates remained constant for the duration of processing run. After this point, both retentate and permeate were collected, cooled to $4^{\circ} \mathrm{C}$ as they were collected, and kept refrigerated at $\leq 4^{\circ} \mathrm{C}$. The typical $\mathrm{Rp}_{\mathrm{i}}$ and $\mathrm{Pp}_{\mathrm{i}}$ were about 428.3 and $203.1 \mathrm{kPa}$ at the top end of the vertical membrane, respectively, and the $\mathrm{Rp}_{\mathrm{o}}$ and $\mathrm{Pp}_{\mathrm{o}}$ were 230.0 and $216.8 \mathrm{kPa}$, respectively, at the bottom end of the vertical membrane. The permeate flux $\left(\mathrm{kg} / \mathrm{m}^{2}\right.$ per hour) was determined every $15 \mathrm{~min}$ as the weight of the permeate collected in $30 \mathrm{~s}$, and samples of permeate and the retentate were taken for analysis by infrared spectrophotometer (Lactoscope FTIR, Delta Instruments) to monitor the composition of the retentate and permeate for process control. At the end of MF run, retentate and permeate were mixed and each was sampled. The average total time of milk processing was about $264 \mathrm{~min}$.

After processing, the GP membrane system was cleaned using the same procedure described for the UTP system. The typical clean water flux before and after processing was about $430 \mathrm{~L} / \mathrm{m}^{2}$ per hour. The water flux was always restored by cleaning. The fouled water flux after processing milk and flushing the system with $50^{\circ} \mathrm{C} \mathrm{RO}$ water was typically about $55 \%$ of the initial clean water flux (435 vs. $241 \mathrm{~kg} / \mathrm{m}^{2}$ per hour).

\section{SW System}

Skim milk (approximately 1,167 kg) was processed at $50^{\circ} \mathrm{C}$ by using a polymeric (polyvinylidene fluoride) spiral-wound membrane (model FG7838-OS0x-S, Parker-Hannifin, Process Advanced Filtration Division, Tell City, IN) with a pore size of about $0.3 \mu \mathrm{m}$ and a surface area of $20.5 \mathrm{~m}^{2}$. The diameter of the membrane was 198 $\mathrm{mm}$, the spacer $1.09 \mathrm{~mm}$, and the length of the module $96.5 \mathrm{~cm}$. The membrane was placed in stainless steel housing (length $1.3 \mathrm{~m}$ ) and was mounted horizontally in the membrane system. The SW MF system consisted of a feed pump (model 0, Cherry Burrel, Little Falls, NY) and retentate recirculation pump (model GHH-30, G\&H Products Corp., Kenosha, WI).

Immediately before milk processing, the SW MF system was cleaned. First, the soak solution $(0.26 \% \mathrm{vol} / \mathrm{vol}$ solution of Ultrasil MP, Ecolab Inc.) was drained from the system, and the membrane was flushed with RO water until the water exiting the system was at neutral $\mathrm{pH}$. The retentate inlet and outlet pressures were set by adjusting the speed of the retentate recirculation pump with the retentate and permeate outlets fully open. The membrane was washed for $20 \mathrm{~min}$ at $\mathrm{Rp}_{\mathrm{i}}$ of 131 $\mathrm{kPa}$ and $\mathrm{Rp}_{\mathrm{o}}$ of $61 \mathrm{kPa}$ with a combination of Ultrasil 110 liquid alkaline membrane cleaner $(0.39 \% \mathrm{vol} / \mathrm{vol})$ and XY-12 liquid sanitizer $(0.15 \% \mathrm{vol} / \mathrm{vol})$ diluted in $50^{\circ} \mathrm{C} \mathrm{RO}$ water at a $\mathrm{pH}$ of 11.2 to 11.4. The operating conditions were set such that the average $\Delta \mathrm{P}(\Delta \mathrm{P}=$ $\left.\left\{\left[\left(\mathrm{Rp}_{\mathrm{i}}-\mathrm{Rp}_{\mathrm{o}}\right) / 2\right]+\mathrm{Rp}_{\mathrm{o}}\right\}-\mathrm{Pp}_{\mathrm{o}}\right)$ was $<100 \mathrm{kPa}$ (mean for 3 replicates was $96 \pm 1.9 \mathrm{kPa}$ ). After the wash cycle was completed, the membrane system was drained and flushed with $50^{\circ} \mathrm{C} \mathrm{RO}$ water until a neutral $\mathrm{pH}$ was obtained. The membrane was cooled to $<24^{\circ} \mathrm{C}$ and sanitized with a solution of Ultrasil 110 liquid alkaline membrane cleaner $(0.39 \% \mathrm{vol} / \mathrm{vol})$ and XY-12 liquid sanitizer $(0.15 \% \mathrm{vol} / \mathrm{vol})$ to achieve a $\mathrm{pH}$ of 11.2 to 11.4 and a chlorine level of 150 to $180 \mathrm{ppm}$ in $\mathrm{RO}$ water. This solution was circulated through the membrane for 10 min at an $\mathrm{Rp}_{\mathrm{i}}$ of $131 \mathrm{kPa}$ with no permeate back pressure. The membrane was drained and flushed with $25^{\circ} \mathrm{C} \mathrm{RO}$ water to neutral $\mathrm{pH}$. The clean water flux was determined by operating only the feed pump with the permeate outlet fully open and an $\mathrm{Rp}_{\mathrm{i}}$ of $35 \mathrm{kPa}$ adjusted by partially opening the retentate bleed valve at $25^{\circ} \mathrm{C}$ with the recirculation loop closed. The water flux (typically about $33 \mathrm{~kg} / \mathrm{m}^{2}$ per hour) was calculated 
based on the weight of permeate collected in $30 \mathrm{~s}$ and the total membrane surface area. The MF system was drained and ready for processing the skim milk.

The SW MF system was started as follows: the feed pump was turned on with the permeate exit valve closed; when the skim milk started exiting the retentate outlet, the retentate recirculation loop valve was opened to allow milk to fill the recirculation loop. Then, the retentate recirculation pump was turned on and the permeate exit valve was opened slowly to balance the pressures and flows of retentate and permeate to achieve $3 \times$ concentration factor and $\Delta \mathrm{P}<100$ $\mathrm{kPa}$. This resulted in a recirculation flow of $239 \pm 1.2$ $\mathrm{L} / \mathrm{min}$. From this point, the retentate and permeate were collected during processing and cooled to $4^{\circ} \mathrm{C}$ as they were collected. The retentate and permeate removal flow rates were adjusted every 10 min to keep the concentration factor at $3 \times$. The average flow of the retentate bleed was $2.76 \pm 0.87 \mathrm{~L} / \mathrm{min}$. The mean $\mathrm{Rp}_{\mathrm{i}}$ was $131.3 \mathrm{kPa}$ and the mean $\mathrm{Rp}_{\mathrm{o}}$ was $60.6 \mathrm{kPa}$. The $\mathrm{Pp}_{\mathrm{o}}$ was equal to $0.00 \mathrm{kPa}$. The flux $\left(\mathrm{kg} / \mathrm{m}^{2}\right.$ per hour) of the membrane was determined every $10 \mathrm{~min}$ as the weight of the permeate collected in $30 \mathrm{~s}$, and samples of permeate and retentate were taken for analysis by infrared spectrophotometer (Lactoscope FTIR, Delta Instruments) to monitor the composition of the retentate and permeate for process control. At the end of the MF run, retentate and permeate were mixed and each was sampled. The average total time of milk processing was about $130 \mathrm{~min}$.

After skim milk processing, the SW MF system was cleaned as follows: first, the MF system was flushed with $150 \mathrm{~L}$ of $50^{\circ} \mathrm{C} \mathrm{RO}$ water at $\mathrm{Rp}_{\mathrm{i}}$ and $\mathrm{Rp}_{\mathrm{o}}$ of 131 and $61 \mathrm{kPa}$, respectively, with no back pressure on the permeate side. During the second rinse using $150 \mathrm{~L}$ of $25^{\circ} \mathrm{C} \mathrm{RO}$ water, the recirculation pump was turned off and the inlet pressure was adjusted to $35 \mathrm{kPa}$ by adjusting the retentate outlet valve. The fouled water flux $\left(\mathrm{kg} / \mathrm{m}^{2}\right.$ per hour) was calculated based on the weight of permeate collected in $30 \mathrm{~s}$ and the membrane area and was typically about $35 \%$ of the clean water flux (33.3 vs. $11.5 \mathrm{~kg} / \mathrm{m}^{2}$ per hour). Each cleaning step was followed by draining the system, which allowed for more rapid and efficient flushing of residual cleaning solution out of the membrane. After determination of the fouled water flux the membrane was washed for 30 min with a combination of Ultrasil 110 liquid alkaline membrane cleaner $(0.39 \% \mathrm{vol} / \mathrm{vol})$ and Ultrasil 01 liquid high surfactant cleaner $\left(0.08 \% \mathrm{vol} / \mathrm{vol}\right.$; Ecolab Inc.) in $50^{\circ} \mathrm{C} \mathrm{RO}$ water at $R p_{i}$ and $R p_{o}$ of 131 and $61 \mathrm{kPa}$, respectively, with no back pressure on the permeate side. These inlet and outlet pressures were used for all cleaning procedures unless otherwise indicated. The $\mathrm{pH}$ of the wash solution was 11.2 to 11.4. After the 30 -min wash, the membrane was flushed to a neutral $\mathrm{pH}$ with $50^{\circ} \mathrm{C} \mathrm{RO}$ water. The membrane was then washed with Ultrasil 76 liquid acid cleaner $(0.15 \% \mathrm{vol} / \mathrm{vol}$; Ecolab Inc. $)$ in $50^{\circ} \mathrm{C}$ $\mathrm{RO}$ water for $30 \mathrm{~min}$. The $\mathrm{pH}$ of the wash solution was 2.0 to 2.2. After the 30 -min wash, the membrane was flushed to a neutral $\mathrm{pH}$ with $50^{\circ} \mathrm{C} \mathrm{RO}$ water. The membrane was then washed for 30 min with a combination of Ultrasil 110 liquid alkaline membrane cleaner $(0.39 \%$ $\mathrm{vol} / \mathrm{vol})$ and XY-12 liquid sanitizer $(0.15 \% \mathrm{vol} / \mathrm{vol})$ in $50^{\circ} \mathrm{C} \mathrm{RO}$ water. The $\mathrm{pH}$ of the wash solution was 11.2 to 11.4 and the chlorine level was 150 to $180 \mathrm{ppm}$. After the 30-min wash, the membrane was flushed to a neutral $\mathrm{pH}$ with $50^{\circ} \mathrm{C} \mathrm{RO}$ water. When the rinse water $\mathrm{pH}$ was neutral, the system was flushed with $\mathrm{RO}$ water at $25^{\circ} \mathrm{C}$ and the clean water flux was determined by operating only the feed pump with the permeate outlet fully open and a retentate inlet pressure of $35 \mathrm{kPa}$ adjusted by the retentate bleed valve and recirculation loop closed. The flux $\left(\mathrm{kg} / \mathrm{m}^{2}\right.$ per hour) was calculated based on the weight of permeate collected in $30 \mathrm{~s}$ and the membrane surface area. The clean water flux after processing was typically about $33 \mathrm{~kg} / \mathrm{m}^{2}$ per hour. After the clean water flux was determined, the membrane was sanitized with a solution of Ultrasil $110(0.39 \%$ $\mathrm{vol} / \mathrm{vol})$ and XY-12 liquid sanitizer $(0.15 \% \mathrm{vol} / \mathrm{vol})$ in $\mathrm{RO}\left(<24^{\circ} \mathrm{C}\right)$ water at $\mathrm{pH} 11.2$ to 11.4 and a chlorine level of 150 to $180 \mathrm{ppm}$. This solution was circulated through the membrane for $10 \mathrm{~min}$ at $\mathrm{Rp}_{\mathrm{i}}$ of $131 \mathrm{kPa}$ with no permeate back pressure. The membrane was then flushed with room temperature $\mathrm{RO}$ water to a neutral $\mathrm{pH}$. After a neutral $\mathrm{pH}$ was obtained, a storage solution of Ultrasil MP soak solution $(0.26 \% \mathrm{vol} /$ vol; Ecolab Inc.) and room temperature RO water were combined to achieve a $\mathrm{pH} 3.5$ to 3.9 , and this solution was circulated through the membrane for $10 \mathrm{~min}$. After $10 \mathrm{~min}$, the pumps were shut off and all the valves on the membrane housing were closed so that the soak solution stayed in contact with the membrane until the next processing day.

\section{Determination of Percentage SP Removal}

The efficiency of removal of SP from skim milk was measured in a mass-balance experiment by measuring the weight of skim milk to be processed and the concentration of SP in the skim milk. The total weight of SP present in the skim milk was calculated. The SP removed from the skim milk was calculated by multiplying the weight of permeate removed by the MF process by the concentration of SP in the permeate. From those values, the total weight of SP removed was calculated. The weight of SP removed divided by the weight of SP at the beginning multiplied by 100 is the percentage SP reduction achieved by the MF process. 


\section{Chemical and Instrumental Analyses}

The samples of raw and pasteurized skim milk before processing were analyzed for total $\mathrm{N}$, noncasein N (NCN), and NPN content using Kjeldahl methods from AOAC (2000; method 991.20, 33.2.11; method 998.05, 33.2.64; and method 991.21; 33.2.12, respectively). Total solids and lactose content of pasteurized skim milk were measured by air oven drying (AOAC, 2000; method 990.20; 33.2.44) and infrared spectrophotometer (Kaylegian et al., 2006), respectively.

Samples of skim milk, permeate, and retentate collected during processing were analyzed using an infrared spectrophotometer (Lactoscope FTIR, Delta Instruments) for fat, lactose, and true protein content (Kaylegian et al., 2006). This was done to quickly monitor the composition of retentate and permeate during the run to detect if the system was running normally.

The samples of final retentate and permeate were analyzed for fat, TS, total N (TN), and NPN content using ether extraction (AOAC, 2000; method 989.05; 33.2.26), forced air oven drying (AOAC, 2000; method 990.20; 33.2.44), Kjeldahl (AOAC, 2000; method 991.20; 33.2.11), and Kjeldahl (AOAC, 2000; method 991.21; 33.2.12), respectively. The NCN content of retentates was determined using Kjeldahl (AOAC, 2000; method 998.05; 33.2.64). True protein was calculated by subtracting NPN from TN and then multiplying by 6.38 ; $\mathrm{CN}$ was calculated by subtracting NCN from TN and multiplying by 6.38 ; and SP content was calculated by subtracting NPN from NCN and multiplying by 6.38 . The SP content in the permeate portion of the skim milk (expressed as a percentage) was calculated by dividing SP in milk by SP in the permeate portion of the milk multiplied by 100 , where the permeate portion of milk is considered as $100 \mathrm{~kg}$ minus the weight of fat plus casein in $100 \mathrm{~kg}$ of milk. All samples were analyzed fresh, except for fat content, for which samples were frozen in $60-\mathrm{mL}$ plastic vials (Capitol Vial, Auburn, $\mathrm{AL})$ at $-80^{\circ} \mathrm{C}$ and then thawed in the microwave to a temperature of $4^{\circ} \mathrm{C}$. The samples were analyzed for fat content by ether extraction immediately after thawing.

\section{Color Analysis of Permeates}

Hunter L (white-black), a (red-green), and b (yellowblue) values for permeates were determined in duplicate with a MacBeth Color-Eye spectrophotometer (model 2020; Kollmorgen Instruments, Corp., Newburgh, NY) using Optiview software from the same company. Hunter color values were computed from the diffuse reflectance data in the 360 to $740 \mathrm{~nm}$ range, at 20-nm intervals, based on illuminant $\mathrm{A}$. The measurements were done at 23 to $25^{\circ} \mathrm{C}$ (Quiñones et al., 1998). The permeate samples for color analysis were taken every 15 min during processing with the UTP and GP systems and every 10 min during processing with SW.

\section{SDS-PAGE}

A 10 to $20 \%$ polyacrylamide gradient was used to determine the relative proportions of protein types in the retentates and permeates from $3 \mathrm{MF}$ systems. The fresh samples $(0.1 \mathrm{~mL})$ were diluted with sample buffer $(0.9 \mathrm{~mL})$ that contained $10 \mathrm{~m} M$ Tris- $\mathrm{HCl}(\mathrm{pH} 6.8), 1.0 \%$ SDS, $20 \%$ glycerol, $0.02 \%$ bromophenol blue tracking dye, and $50 \mathrm{~m} M$ dithiothreitol, and stored frozen. The samples were thawed at room temperature before the analysis. The diluted samples in glass vials (Target DP Vials C4000-1W, National Scientific Company, Rockwood, TN) sealed with DP Blue Cap caps (C4000-51B, National Scientific Company) were heated to $100^{\circ} \mathrm{C}$ in a steam chamber and held for $3 \mathrm{~min}$. The permeates, retentates, and milk were loaded $(30,10$, and $8.5 \mu \mathrm{L}$, respectively) onto an SDS-PAGE gel, and the procedure of Verdi et al. (1987) was used for running, staining, and destaining the gels. The gels were scanned with USB GS 800 Densitometer using Quantity One 1-D Analysis Software (Bio-Rad Laboratories Inc., Hercules, CA) to obtain relative protein proportions within each sample. The loading of the samples on the SDS-PAGE gel was chosen to achieve the maximum optical density (OD) of the predominant protein in each sample in the range of 1.0 to 1.4 OD. A milk sample was run on each gel as a reference for proper resolution of milk proteins and a check for consistency of quantitative analysis from gel to gel. The background was adjusted separately for each lane using the rolling disk method of subtraction to obtain a flat base on the pop-up trace. The line that defines each lane was adjusted using the lane tools functions (add/adjust anchors) in the software, so that the red lane line crossed each band at the center. The adjust band function of the software was used with brackets to set the leading and trailing edge for each band as visually observed on the image of the gel, not based on the beginning and end of the peak in the popup trace. The width of the brackets within each lane was set for all bands in that lane to be slightly wider than the widest band in that lane.

\section{RESULTS AND DISCUSSION}

\section{Processing}

The mean $(\mathrm{n}=3)$ pressures during operation of the UTP, GP, and SW systems are shown in Figures 1 ( $\mathrm{a}, \mathrm{b}, \mathrm{c})$. Transmembrane pressure at the retentate 
inlet end was higher than at the retentate outlet end for all 3 types of membranes. The difference in TMP between the retentate inlet and outlet was greatest for GP (Figure 1b) and smallest for UTP (Figure 1a). The TMP at the inlet and outlet ends of the membrane remained relatively constant during the run for UTP and SW (Figures 1a, c), but increased with time during the run for GP membranes (Figure 1b) as a result of a decrease in $\mathrm{Pp}_{\mathrm{o}}$. In the operation of the GP membrane, the permeate removal rate, which is controlled with the permeate bleed valve, is restricted to avoid a negative TMP at the retentate outlet end of the membrane. As can be seen from Figure 1b, a positive TMP at the retentate outlet end of the membrane was not achieved at the beginning of the run, and a negative TMP causes flow of permeate back into the retentate side of the membrane near the retentate outlet end of the membrane. Back flow of permeate into the retentate side of the membrane is called Starling flow (Heath et al., 1990; Dai et al., 2000). The increase in TMP for the GP membranes during the run (Figure 1b) may indicate that fouling is occurring during the run. During the 264 min of the GP system operation, $R p_{i}$ and $R p_{o}$ remained the same but $\mathrm{Pp}_{\mathrm{i}}$ and $\mathrm{Pp}_{\mathrm{o}}$ decreased from an average (mean of 3 replicates) initial value of $222 \pm 3.8$ and 236 $\pm 3.8 \mathrm{kPa}$ to an average of $193 \pm 8.7$ and $206 \pm 8.7$ $\mathrm{kPa}$, respectively, at the end of the processing, which caused the TMP at the inlet and outlet ends of the membrane to increase gradually with time of running. Because the total permeate removal rate for the GP system was intentionally restricted by the setting of the permeate exit valve during the run to maintain a $3 \times$ concentration factor, the decrease in pressure on the permeate side of the membrane did not affect the measured permeate removal rate during the processing time in this study; however, it can be expected that, in a longer processing run, the permeate removal rate will not be able to be maintained when the $\mathrm{Pp}_{\mathrm{i}}$ decreases to $0 \mathrm{kPa}$. When this happens, the retentate removal rate will have to be decreased to match proportionately the permeate removal rate to maintain a $3 \times$ concentration factor. Thus, the total amount of milk processed per hour will decrease. For all $3 \mathrm{MF}$ systems, cleaning restored the clean water flux that was determined before the run.

A difference $(P<0.05)$ in flux $\left(\mathrm{kg} / \mathrm{m}^{2}\right.$ per hour $)$ among the 3 different MF systems was detected (Table 1). The GP system had the highest flux and the SW system had the lowest (Table 1). These differences in flux would influence the amount of membrane surface area needed in a factory to process a given volume of milk. As shown in Figure 2, the GP and UTP membranes were characterized by consistent flux during processing, whereas the flux of SW system decreased
$(P<0.05)$ during the initial $30 \mathrm{~min}$ and then continued to decrease gradually $(P<0.05)$ with increasing time of processing. Based on the weight of the skim milk used for processing and the MF retentate collected, the mean concentration factors (wt/wt) were $3.00 \pm 0.03$, $2.99 \pm 0.02$, and $3.07 \pm 0.09$ for UTP, GP, and SW, respectively.

\section{Composition}

Skim Milk. The compositions of the raw and pasteurized skim milk used in this study are shown in Table 2. The casein as a percentage of true protein (CN\% TP) of the milks used in this study was typical of good-quality raw milk. Thermal processing of milk is known to cause denaturation of milk SP and formation of intermolecular disulfide bonds between $\beta-\mathrm{LG}$ and $\kappa$-CN (Harland et al., 1952). The skim milk used in our study was pasteurized. The parameters of pasteurization (minimum temperature and time, $72^{\circ} \mathrm{C}$ for $16 \mathrm{~s}$ ) in our study were chosen to achieve pasteurization but to produce minimal heat denaturation of SP and binding of SP to casein. Excessive heat-induced binding of SP to casein before MF would be expected to reduce the ability of MF to separate SP from casein. Measurement of $\mathrm{CN} \% \mathrm{TP}$ and the difference in this value before and after pasteurization is an indication of the degree of denaturation of SP. Given the number of replicates, we could not detect $(P>0.05)$ an increase in CN\%TP in the pasteurized milk (82.38\%) compared with the raw milk $(81.96 \%)$ used in our study (Table 2). Ma et al. (2000) reported that the increase in CN\%TP in commercial fluid milk pasteurized at $74^{\circ} \mathrm{C}$ for $34 \mathrm{~s}$ was about $3 \%$, which suggests that the heat-treatment conditions used in our study produced minimal heat denaturation of SP. Thus, even a $2^{\circ} \mathrm{C}$ higher pasteurization temperature and a longer holding time would produce a significant amount of protein denaturation and would reduce the amount of SP that could be removed by microfiltration. The calculated mean SP content in the MF permeate portion (i.e., the fat- and casein-free skim milk) of the skim milk was $0.58 \%$. The SP concentration in the permeate portion of the milk is an estimate of the maximum concentration of SP that can be expected in the MF permeate if the coefficient of rejection of SP by the membrane is zero.

Permeate. The compositions of the MF permeates are shown in Table 3. The TS content of permeate differed significantly among membrane processes with higher TS for permeates from ceramic membranes. The fat content of all MF permeates was very low, and no difference $(P>0.05)$ in fat content among permeates obtained from UTP, GP, and SW MF systems was detected (Table 3). Because a high content of fat in whey 

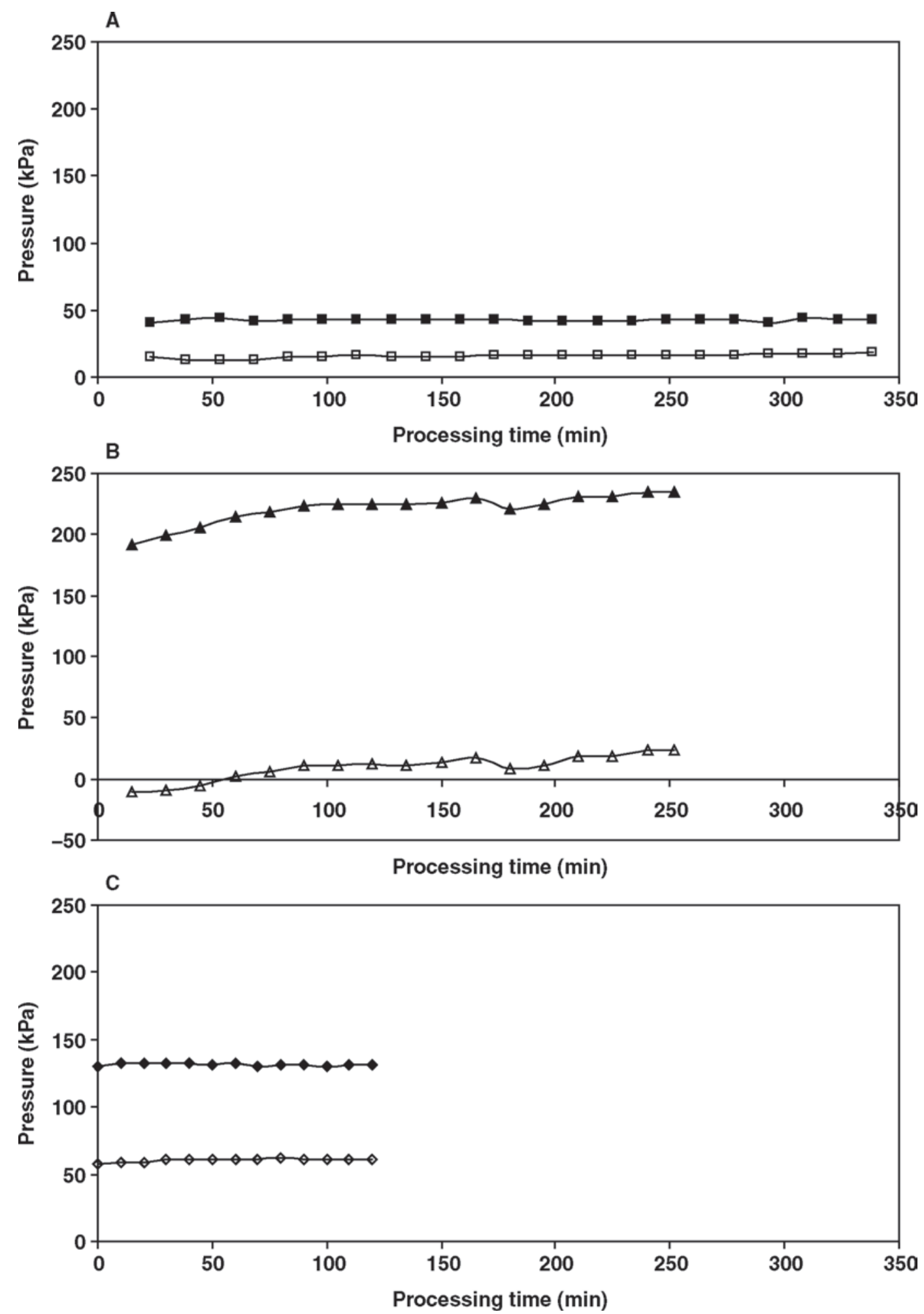

Figure 1. Mean $(\mathrm{n}=3)$ change in transmembrane pressure with time of processing at retentate inlet $\left(\mathrm{TMP}_{\mathrm{i}}\right)$ and outlet $\left(\mathrm{TMP}_{\mathrm{o}}\right)$ of the membrane: a) $\operatorname{TMP}_{\mathrm{i}}(\mathbf{\square})$ and $\operatorname{TMP}_{\mathrm{o}}(\square)$ of uniform transmembrane pressure system; b) $\mathrm{TMP}_{\mathrm{i}}(\mathbf{\Delta})$ and $\mathrm{TMP}_{\mathrm{o}}(\Delta)$ of graded permeability system; c) $\mathrm{TMP}_{\mathrm{i}}(\bullet)$ and $(\diamond) \mathrm{TMP}_{\mathrm{o}}$ of spiral wound system. 
Table 1. Mean $(\mathrm{n}=3)$ flux for ceramic uniform transmembrane pressure (UTP), ceramic graded permeability (GP), and polymeric spiral-wound (SW) membranes during skim milk processing at $50^{\circ} \mathrm{C}$

\begin{tabular}{lcl}
\hline Membrane process & Flux $\left(\mathrm{kg} / \mathrm{m}^{2}\right.$ per hour $)$ & $\mathrm{SD}$ \\
\hline UTP & $54.08^{\mathrm{b}}$ & \pm 1.52 \\
GP & $71.79^{\mathrm{a}}$ & \pm 1.68 \\
SW & $16.21^{\mathrm{c}}$ & \pm 4.75 \\
\hline
\end{tabular}

${ }^{\mathrm{a}-\mathrm{c}}$ Means in the same column not sharing a common superscript are different $(P<0.05)$.

protein concentrates obtained from whey after cheese production has a negative effect on flavor (Morr and Ha, 1991) and foaming (Pearce et al., 1992), very little fat content in SP products produced directly from skim milk using MF may produce serum protein concentrate products with superior functional properties to whey protein concentrates. The true protein content of the MF permeates from UTP and GP was higher $(P<$ $0.05)$ than that of the permeate from SW membranes (Table 3). The higher protein content of permeate from the ceramic membranes explains the higher solids content in permeates from ceramic membranes compared with those from the polymeric membranes.

Lower protein content of permeate from SW membranes indicates that some of the SP were rejected by the SW membrane, which may result in a lower rate of $\mathrm{SP}$ removal. The true protein concentration in the UTP permeate $(0.57 \%)$ was very close to the SP concentration in the permeate portion of the skim milk $(0.58 \%)$, which would indicate very little rejection of SP by the UTP membrane, whereas the true protein content of the permeate from the SW membranes $(0.38 \%)$ would indicate rejection of SP by spiral-wound polyvinylidene fluoride membranes in our study. In another study (Govindasamy-Lucey et al., 2007) of MF of skim milk at a lower temperature $\left(<7^{\circ} \mathrm{C}\right)$ with spiral-wound polyvinylidene fluoride membranes (pore size of $0.2 \mu \mathrm{m}$ ), a true protein content of permeate $(0.21 \%)$ was reported, which is even lower than our observation at $50^{\circ} \mathrm{C}$. Thus, it is likely that SP content of permeate may decrease with operation temperature with SW membranes.

There was a difference in the permeate appearance during start-up of the 3 systems. The ceramic UTP and GP permeates were clear during the transition from water to milk, whereas permeate from the SW membrane was very cloudy at the beginning of the permeate flow. Within about 2 or 3 min of operation, the clarity of permeate from the SW system increased. In the SW polymeric membranes, separation of casein and SP is dependent on the formation of a boundary layer of milk proteins on the surface of the membrane. While the boundary layer was forming, permeate from the SW MF membrane contained a significant amount of casein. The hydrophilic nature of the ceramic membranes results in lower protein adsorption to the membrane compared with hydrophobic polymeric membranes (Baruah et al., 2006). In the ceramic membranes the separation of casein and SP is controlled by the porosity of the membrane and the lift of the casein micelles that is generated by the shear stress due to high flow velocity, which explains the difference in the appearance between SW membrane permeate and ceramic membrane permeate during the first few minutes of filtration. The Hunter Lvalue of MF permeate can be used as an index of clarity, with samples having lower L-values being more clear. The mean L-value of MF permeates for UTP, GP, and

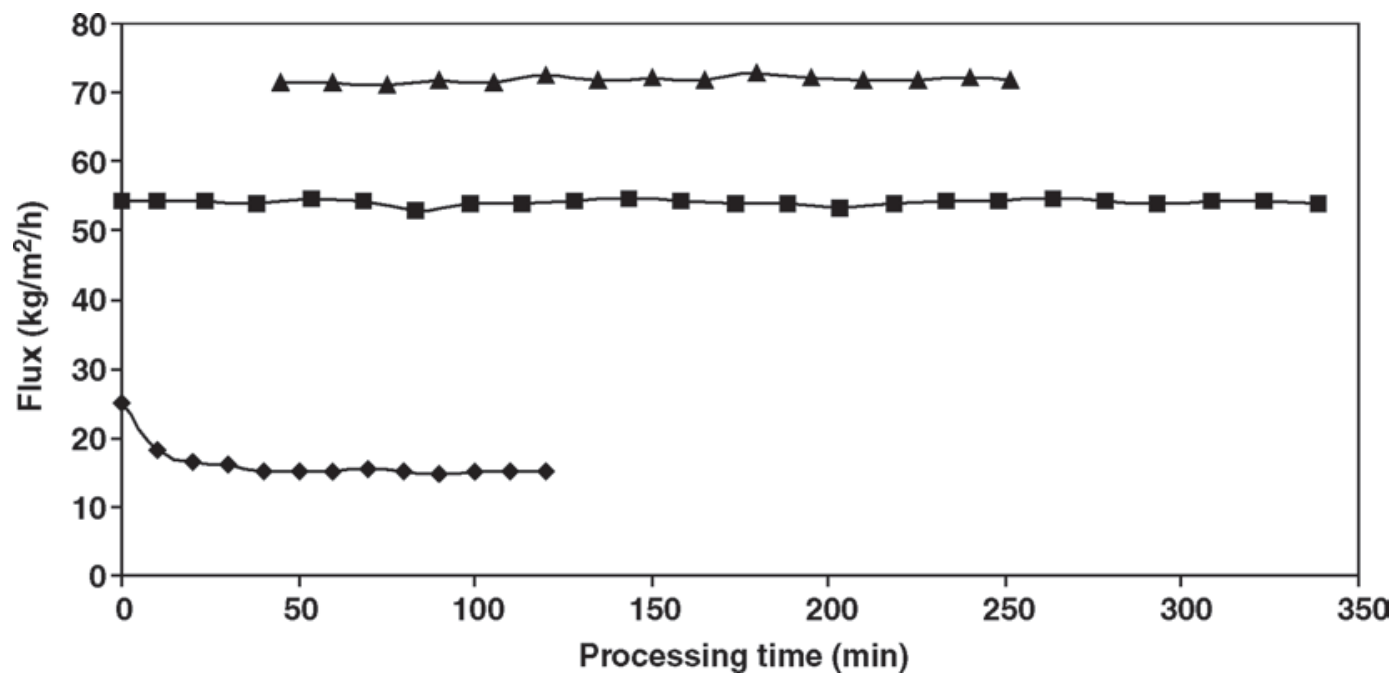

Figure 2. Mean $(\mathrm{n}=3$ ) flux of ceramic uniform transmembrane pressure $(\mathbf{\square})$, ceramic graded permeability ( $\mathbf{\Delta})$, and polymeric spiral-wound ( ) membranes during processing of skim milk at $50^{\circ} \mathrm{C}$. 
Table 2. Mean $(\mathrm{n}=3)$ composition of raw and pasteurized skim milks (\% by weight)

\begin{tabular}{|c|c|c|c|c|c|c|c|c|c|}
\hline \multirow[b]{2}{*}{ Milk treatment } & \multicolumn{9}{|c|}{ Composition $^{1}$} \\
\hline & TS & $\mathrm{TN}$ & $\mathrm{NCN}$ & NPN & $\mathrm{TP}$ & Casein & $\mathrm{CN} \% \mathrm{TP}$ & $\begin{array}{l}\text { Serum } \\
\text { proteins }\end{array}$ & Lactose \\
\hline Pasteurized & 9.21 & 3.39 & 0.75 & 0.19 & 3.20 & 2.64 & 82.38 & 0.56 & 4.76 \\
\hline Raw & - & 3.41 & 0.77 & 0.18 & 3.22 & 2.64 & 81.96 & 0.58 & - \\
\hline
\end{tabular}

SW with time of processing are shown in Figure 3. The L-value (i.e., clarity) of UTP permeate remained the same throughout processing, whereas for GP and SW, run-time-dependent changes in L-value were observed. The L-value of GP permeate increased slightly during the first $100 \mathrm{~min}$ of processing and then remained relatively constant. This increase in L-value was caused by the slow transition from water to MF permeate in the permeate side of the membrane housing. There was a large decrease in the L-value of SW permeate at the beginning of the processing run, and after 40 min the opacity of the SW permeate remained constant and was at the same level as for GP (Figure 3). During the first 2 min of running the SW system, the MF permeate had the white appearance of skim milk, but it increased in clarity relatively quickly as a milk protein foulant layer was deposited on the retentate side of the membrane causing a change in the membrane rejection characteristics. The difference in appearance between the final permeates of UTP, GP, and SW is shown in Figure 4, with the UTP permeate being the most clear. No significant differences $(P>0.05)$ in Hunter a- or bvalues among permeates produced by the 3 membrane systems were detected (Table 2). The results from SDSPAGE revealed the presence of casein bands in all of the MF permeates; however, the bands in GP and SW permeates were more intense than in the UTP permeate (Figure 5) at the same loading of samples. The true protein (TP) content of SW permeate was significantly lower than that of permeate produced with ceramic membranes; therefore, at the same loading of proteins per lane, the casein bands of SW permeate would be more similar to the GP permeate. Casein content in GP and SW permeates could have caused the higher opacity of the GP and SW permeates. There was a significant difference in Hunter color values among the MF permeates (Table 4). Generally, higher L-value is related to higher opacity; the UTP permeate had significantly lower opacity than both GP and SW. The differences were visible at low protein concentration (Figure 4). After concentrating the permeate in further processing, it would be expected that the differences in the clarity among MF permeates will be increased, which may be an important parameter when protein products produced from MF permeates are used for fortification of clear, nondairy beverages.

Retentate. The composition of the MF retentates is shown in Table 5. There were differences in TS and TP content among the retentates but a portion of these differences would be expected because of small differences in the actual concentration factor achieved in the processes. As indicated earlier in this paper, the actual concentration factors were $3.00,2.99$, and 3.07 for UTP, GP, and SW, respectively. The TS and TP concentrations of SW retentates were expected to be higher than those of UTP and GP because of the slightly higher concentration factor, but the data in Table 5 showed that they were significantly lower, which was not ex-

Table 3. Mean $(\mathrm{n}=3)$ composition ( $\%$ by weight) of permeates produced with 3 different microfiltration membranes: ceramic uniform transmembrane pressure (UTP), ceramic graded permeability (GP), and polymeric spiral wound (SW)

\begin{tabular}{lccccc}
\hline & \multicolumn{5}{c}{ Composition $^{1}$} \\
\cline { 2 - 6 } Membrane process & TS & Fat & TN & NPN & TP \\
\hline UTP & $6.27^{\mathrm{b}}$ & 0.0023 & $0.75^{\mathrm{a}}$ & 0.18 & $0.57^{\mathrm{a}}$ \\
GP & $6.35^{\mathrm{a}}$ & 0.0010 & $0.74^{\mathrm{a}}$ & 0.18 & $0.56^{\mathrm{a}}$ \\
SW & $6.18^{\mathrm{c}}$ & 0.0015 & $0.56^{\mathrm{b}}$ & 0.18 & $0.38^{\mathrm{b}}$ \\
\hline
\end{tabular}

${ }^{\mathrm{a}-\mathrm{c}}$ Means in the same column not sharing a common superscript are different $(P<0.05)$.

${ }^{1} \mathrm{TS}=$ total solids; $\mathrm{TN}=$ total nitrogen $\times 6.38 ; \mathrm{NCN}=$ noncasein nitrogen $\times 6.38 ; \mathrm{NPN}=$ nonprotein nitrogen $\times 6.38 ; \mathrm{TP}=$ true protein $(\mathrm{TN}-\mathrm{NPN})$. 


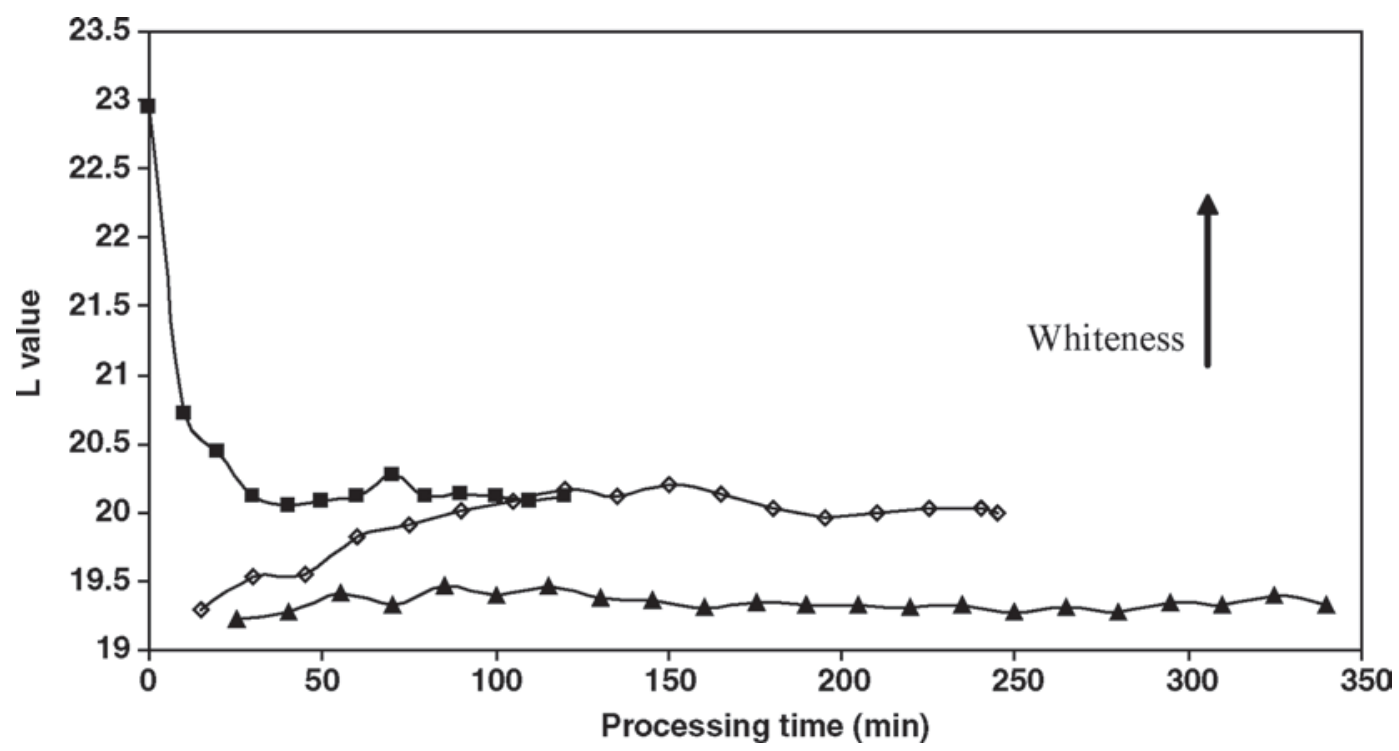

Figure 3. Changes in Hunter L (whiteness) color values of uniform transmembrane pressure permeate ( $\mathbf{\Lambda}$ ), graded permeability permeate $(\diamond)$ and spiral wound permeate $(\mathbf{\square})$ during processing of skim milk.

pected. The difference in TS between SW and UTP was almost equal to the difference in protein $(\mathrm{TN} \times 6.38)$ content between them. Therefore, the differences in composition among the retentates, particularly the SW retentate, did not reflect the expected differences due to concentration factor or the lower removal of SP in permeate. More research is needed to explain this phenomenon. The membrane surface area in the SW MF

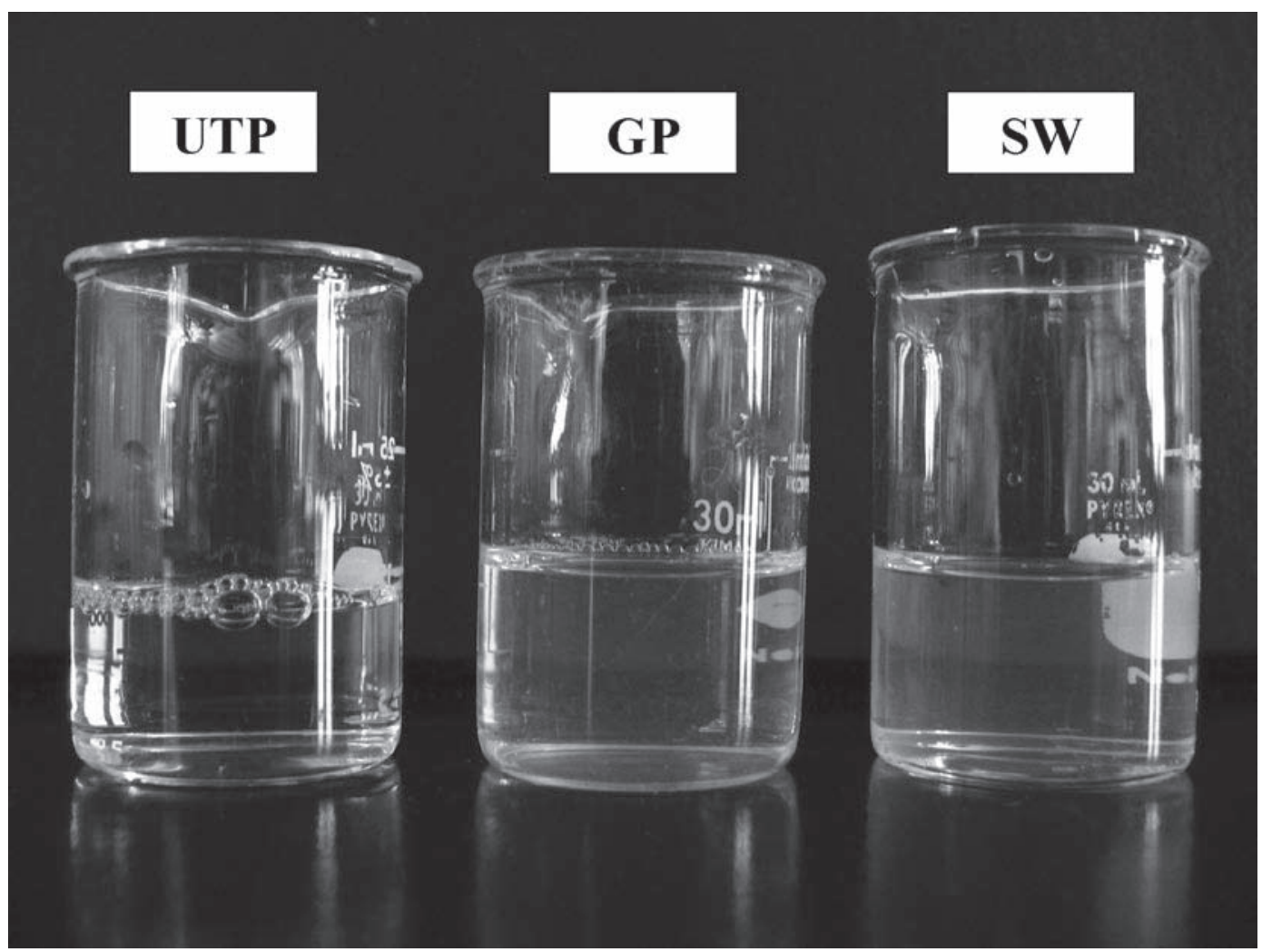

Figure 4. Appearance of microfiltration permeates (composite sample) from left to right: ceramic uniform transmembrane pressure (UTP), ceramic graded permeability (GP), and polymeric spiral wound (SW). 
Table 4. Mean $(\mathrm{n}=3)$ Hunter L (white-black), a (red-green), and b (yellow-blue) color values for permeates produced with 3 different microfiltration membranes: ceramic uniform transmembrane pressure (UTP), ceramic graded permeability (GP), and polymeric spiral wound (SW)

\begin{tabular}{lccc}
\hline Membrane process & $\mathrm{L}$ & $\mathrm{a}$ & $\mathrm{b}$ \\
\hline UTP & $19.34^{\mathrm{b}}$ & -1.05 & 1.13 \\
GP & $20.00^{\mathrm{a}}$ & -1.22 & 0.73 \\
SW & $20.11^{\mathrm{a}}$ & -1.23 & 0.78 \\
\hline
\end{tabular}

${ }^{\mathrm{a}, \mathrm{b}}$ Means in the same column not sharing a common superscript are different $(P<0.05)$.

system was much larger than in the ceramic systems. In addition, there is a very large surface area of other polymeric support materials within the SW membrane. It appears that there may be a fixed loss of milk solids (particularly proteins) adsorbed to polymeric surfaces, which may explain the disappearance of protein and solids in the retentate in the SW system relative to the 2 ceramic membrane systems. The limitations of the accuracy of the NCN method that was designed for milk when applied to MF retentate samples have been described previously (Nelson and Barbano, 2005). However, the relative comparison of NCN among the 3 permeates in this study is probably valid. The higher NCN content of the SW retentate, indicating higher $\mathrm{SP}$ content of the SW retentate compared with the retentates from ceramic membranes, is consistent with the lower concentration of SP in the permeate from SW membranes compared with ceramic (Table 3). The higher SP content of the retentate from SW membranes resulted in a lower $(P<0.05) \mathrm{CN} \% \mathrm{TP}$ (Table 5$)$.

\section{Electrophoresis}

A typical SDS-PAGE gel for MF permeates is shown in Figure 5 and for retentates in Figure 6. The samples of permeates were prepared in the same manner and loaded at the same level, but the amount of protein loaded in the lanes differs because of the differences in TP content among the permeates and retentates from polymeric and ceramic membranes. The $\beta-\mathrm{LG}$ and $\alpha-\mathrm{LA}$ contents of permeates and retentates were calculated as relative proportions and are presented in Tables 6 and 7 , respectively. Content of $\beta$-LG in SW permeate was significantly lower (Table 6) than for both ceramic GP and UTP membranes. Measured separately, the proportion of $\beta$-LG to $\alpha$-LA in SW retentate was higher than for UTP and GP retentates (Table 7). Thus, more $\beta-L G$ passed through the ceramic membranes than through the polymeric membrane. Other researchers (Lawrence et al., 2008) have reported a high rejection of $\beta$-LG $(78,88,92$, and $99 \%$ at TMP of $50,100,150$, and $258 \mathrm{kPa}$, respectively) when using SW polymeric membranes similar to those used in our study. The mean relative proportions of $\beta-\mathrm{LG}$ and $\alpha-\mathrm{LA}$ in milk used in our study were 78.15 and $21.85 \%$, respectively. The proportion of $\beta$-LG and $\alpha$-LA in the retentates (Table 7) from ceramic membranes were very similar to the starting milk, indicating very little rejection of $\beta$-LG by the ceramic membranes.

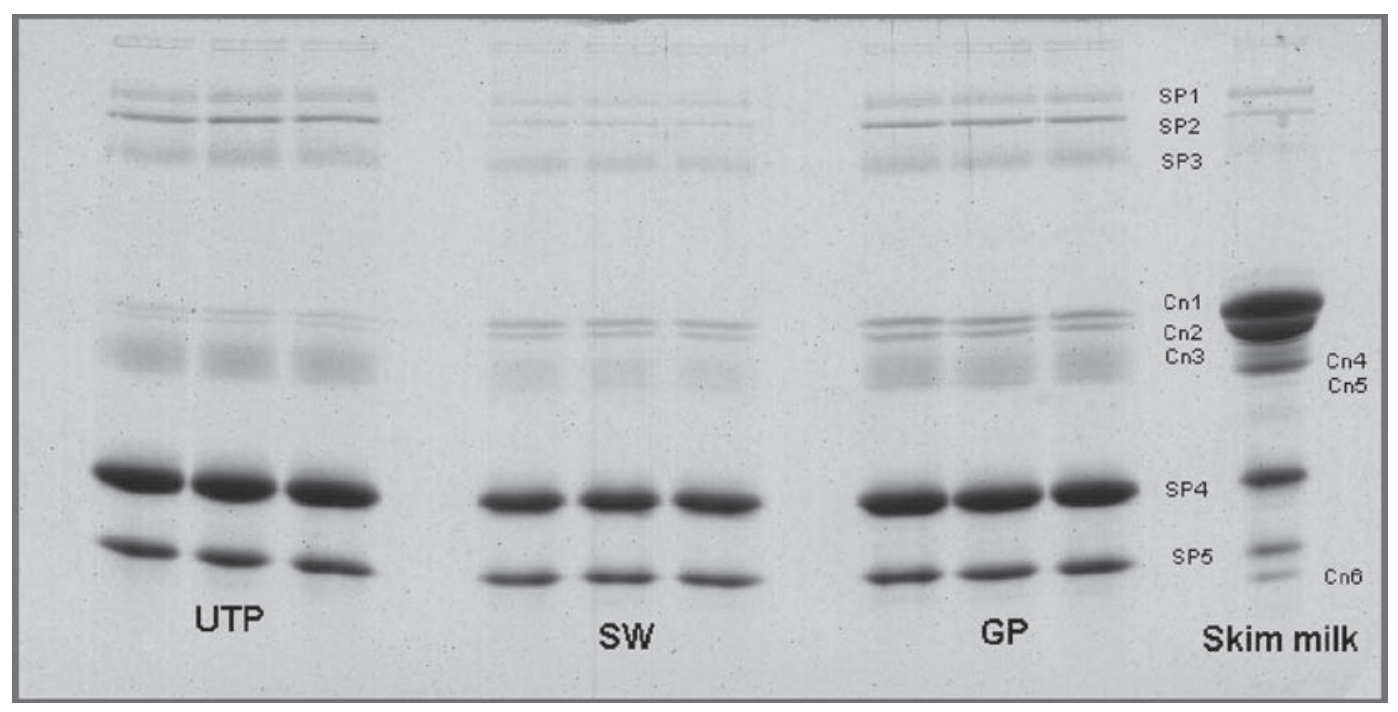

Figure 5. The proteins in skim milk and the microfiltration permeates produced by ceramic uniform transmembrane pressure (UTP), polymeric spiral wound (SW), and ceramic graded permeability (GP) membranes separated using SDS-PAGE. Bands in skim milk are identified on the gel: SP1, SP2, and SP3 = serum proteins; CN1 $=\alpha_{\mathrm{S}}-\mathrm{CN}$ (combination of $\alpha_{\mathrm{S} 1}$ and $\left.\alpha_{\mathrm{S}_{2}} \mathrm{CN}\right)$; CN2 $=\beta-\mathrm{CN}$; CN4 $=\kappa-\mathrm{CN}$; CN3, CN5, and $\mathrm{CN} 6=$ proteolysis products of casein; SP $4=\beta$-LG; and SP $5=\alpha-\mathrm{LA}$. 


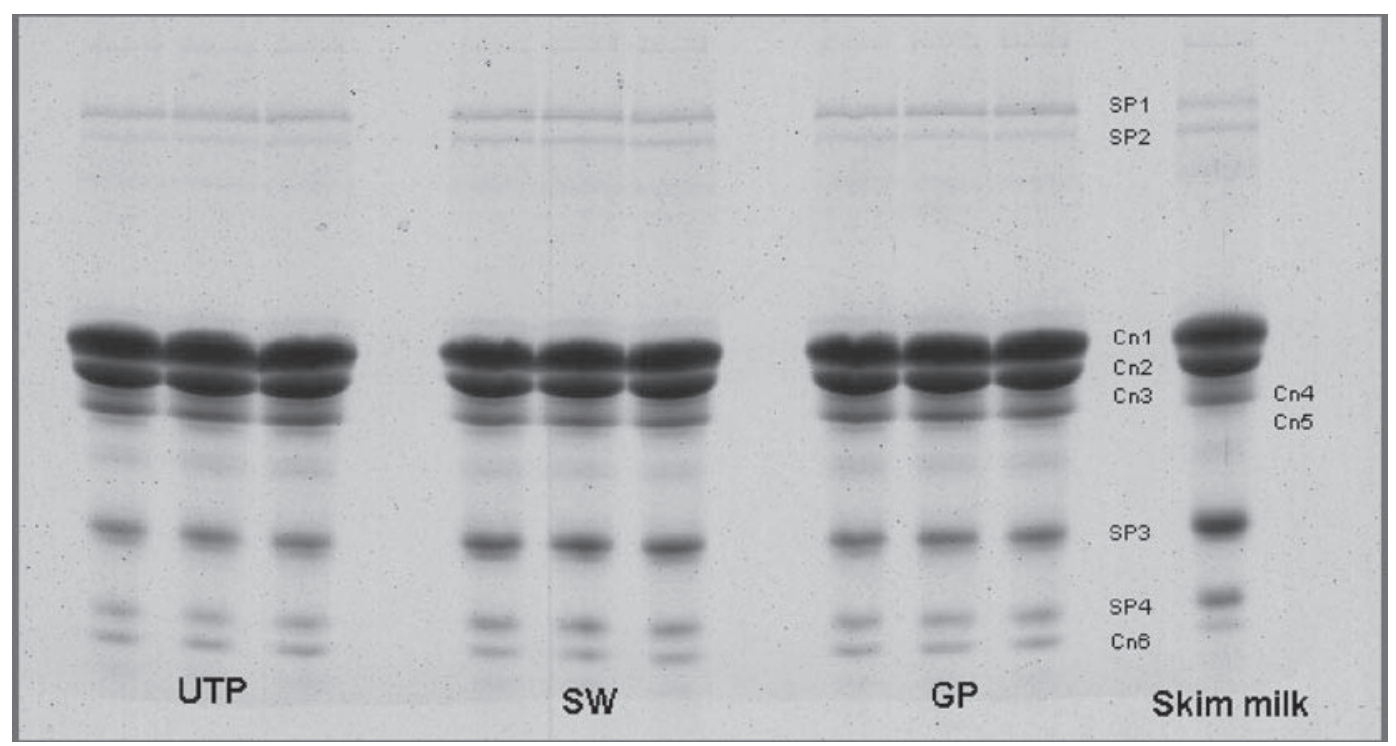

Figure 6. The proteins in skim milk and the microfiltration retentates produced by ceramic uniform transmembrane pressure (UTP), polymeric spiral wound (SW), and graded permeability (GP) membranes separated using SDS-PAGE. Bands in skim milk are identified on the gel: $\mathrm{SP} 1$ and SP2 = serum proteins; $\mathrm{CN} 1=\alpha_{\mathrm{S}} \mathrm{CN}$ (combination of $\alpha_{\mathrm{S} 1}$ and $\alpha_{\mathrm{S}_{2}-\mathrm{CN}}$ ); $\mathrm{CN} 2=\beta-\mathrm{CN}$; CN4 $=\kappa-\mathrm{CN}$; CN3, CN5, and CN6 = proteolysis products of casein; SP3 $=\beta$-LG; and SP $4=\alpha$-LA.

When the densitometry analysis of the SDS-PAGE gels for permeates was done including all major bands on the gels, differences $(P<0.05)$ in the relative proportion of casein to SP (Table 8) between the permeates were measured. The GP permeate had the highest casein proportion, followed by SW and then UTP, suggesting the highest passage of casein through the GP membrane. In product applications using milk SP isolates (i.e., $>90 \%$ protein on a solids basis) produced by microfiltration of milk for fortification of clear beverages (such as flavored waters), the residual level of casein in the MF permeate may be a limiting factor in maintaining clarity in shelf-stable protein-fortified clear beverages. The presence of casein and its higher proportion in GP and SW permeates compared with the UTP permeate may explain the difference in the appearance (Figure 4) of the final permeates. In ce- ramic membrane systems, the separation of milk casein and SP is produced by the combination of the pore size of the membrane and the lift on the casein micelles created by turbulent flow (Altmann and Ripperger, 1997). There is a range of casein micelle diameters, and the amount of lift by turbulent flow will differ between the smallest and largest casein micelles. Under the processing conditions $\left(50^{\circ} \mathrm{C}\right.$, linear retentate flow $7.75 \mathrm{~m} / \mathrm{s}$, $777 \mathrm{~L} / \mathrm{min}$ ) used in our GP system, there may not have been enough lift of the small particles (i.e., small casein micelles) and some passed through the GP membrane. As reported by Altmann and Ripperger (1997), the lift force is lower than the drag force at high filtration rates, especially for the small particles, which means that the smallest particles will be transported to the membrane surface and will be deposited on the membrane or will pass through it. The flux for the GP membranes was

Table 5. Mean ( $\mathrm{n}=3$ ) composition (\% by weight) of the retentates produced with 3 different microfiltration membranes: ceramic uniform transmembrane pressure (UTP), ceramic graded permeability (GP), and polymeric spiral wound (SW)

\begin{tabular}{lcccccccc}
\hline & \multicolumn{7}{c}{ Composition $^{1}$} \\
\cline { 2 - 8 } Membrane process & TS & TN & NP & NCN & TP & Casein & CN\%TP & Serum proteins \\
\hline UTP & $15.03^{\mathrm{a}}$ & $8.87^{\mathrm{a}}$ & 0.18 & $0.97^{\mathrm{c}}$ & $8.70^{\mathrm{a}}$ & $7.90^{\mathrm{a}}$ & $90.84^{\mathrm{a}}$ & $0.80^{\mathrm{c}}$ \\
GP & $14.50^{\mathrm{b}}$ & $8.46^{\mathrm{b}}$ & 0.18 & $1.01^{\mathrm{b}}$ & $8.28^{\mathrm{b}}$ & $7.45^{\mathrm{b}}$ & $89.96^{\mathrm{b}}$ & $0.83^{\mathrm{b}}$ \\
SW & $13.96^{\mathrm{c}}$ & $7.97^{\mathrm{c}}$ & 0.18 & $1.24^{\mathrm{a}}$ & $7.79^{\mathrm{c}}$ & $6.73^{\mathrm{c}}$ & $86.35^{\mathrm{c}}$ & $1.06^{\mathrm{a}}$ \\
\hline
\end{tabular}

${ }^{\mathrm{a}-\mathrm{c}}$ Means in the same column not sharing a common superscript are different $(P<0.05)$.

${ }^{1} \mathrm{TS}=$ total solids; $\mathrm{TN}=$ total nitrogen $\times 6.38 ; \mathrm{NPN}=$ nonprotein nitrogen $\times 6.38 ; \mathrm{NCN}=$ noncasein nitrogen $\times 6.38 ; \mathrm{TP}=$ true protein $(\mathrm{TN}-\mathrm{NPN})$; casein $=(\mathrm{TN}-\mathrm{NCN})$; $\mathrm{CN} \% \mathrm{TP}=$ casein as percentage of true protein; and serum proteins $=(\mathrm{TP}-$ casein $)$. 
Table 6. Mean $(n=3)$ relative quantities of $\beta$-LG and $\alpha$-LA for permeates produced using ceramic uniform transmembrane pressure (UTP), ceramic graded permeability (GP), and polymeric spiralwound (SW) membranes by the densitometry analysis of the SDSPAGE gels

\begin{tabular}{lll}
\hline Membrane process & $\beta-\mathrm{LG}$ & $\alpha-\mathrm{LA}$ \\
\hline UTP & $76.04^{\mathrm{a}}$ & $23.96^{\mathrm{b}}$ \\
GP & $76.31^{\mathrm{a}}$ & $23.69^{\mathrm{b}}$ \\
SW & $73.28^{\mathrm{b}}$ & $26.72^{\mathrm{a}}$ \\
\hline
\end{tabular}

${ }^{\mathrm{a}, \mathrm{b}}$ Means in the same column not sharing a common superscript are different $(P<0.05)$.

higher than for the UTP membranes in our study (Table 1), but the GP and UTP membranes were run under identical flow and temperature conditions. Therefore, in the UTP system with the lower permeation rate, the lift on the smaller casein micelles would have been greater than in the GP system, which might explain the higher level of casein in the GP permeate (Table 8). Assuming that the hypothesis is correct that there is not sufficient lift on the small casein micelles to prevent them from passing through the membrane, then restricting the permeate removal rate (i.e., reducing it from 72 to $54 \mathrm{~kg} / \mathrm{m}^{2}$ per hour) for the GP membranes may have resulted in a reduced casein content of the GP permeate, improved permeate clarity, and reduced the membrane fouling. Also, the relative proportion of the 2 major casein bands in the permeate (Figure 6) appears similar to that found in milk, which would be consistent with small casein micelles passing through the membrane versus passage of nonmicellar individual casein monomers through the membrane.

The average relative proportions of total casein and $\mathrm{SP}$ in the retentates determined by SDS-PAGE are shown in Table 9. The SP content among the retentates produced by different membrane systems was different $(P<0.05)$, with the highest SP content in retentates produced with SW membranes. The SDS-PAGE data are consistent with the Kjeldahl data for retentate composition in Table 5.

Table 7. Mean $(n=3)$ relative quantities of $\beta$-LG and $\alpha$-LA for retentates produced using ceramic uniform transmembrane pressure (UTP), ceramic graded permeability (GP), and polymeric spiralwound (SW) membranes by the densitometry analysis of the SDSPAGE gels

\begin{tabular}{lll}
\hline Membrane process & $\beta-\mathrm{LG}$ & $\alpha-\mathrm{LA}$ \\
\hline UTP & $78.41^{\mathrm{b}}$ & $21.59^{\mathrm{a}}$ \\
GP & $78.76^{\mathrm{b}}$ & $21.24^{\mathrm{a}}$ \\
SW & $80.88^{\mathrm{a}}$ & $19.12^{\mathrm{b}}$ \\
\hline
\end{tabular}

${ }^{\mathrm{a}, \mathrm{b}}$ Means in the same column not sharing a common superscript are different $(P<0.05)$.
Table 8. Mean $(\mathrm{n}=3)$ relative proportions of casein to serum proteins for permeates produced using ceramic uniform transmembrane pressure (UTP), ceramic graded permeability (GP), and polymeric spiral-wound (SW) membranes by densitometry analysis of the SDSPAGE gels

\begin{tabular}{lcc}
\hline Membrane process & Casein & Serum proteins \\
\hline UTP & $1.23^{\mathrm{c}}$ & $98.77^{\mathrm{a}}$ \\
GP & $4.93^{\mathrm{a}}$ & $95.07^{\mathrm{c}}$ \\
SW & $3.82^{\mathrm{b}}$ & $96.18^{\mathrm{b}}$ \\
\hline
\end{tabular}

${ }^{\mathrm{a}-\mathrm{c}}$ Means in the same column not sharing a common superscript are different $(P<0.05)$.

\section{Serum Protein Removal}

The economics of an MF process will depend on both the processing costs to produce the milk protein fractions and the efficiency and completeness of separation of the casein and SP. Measurement of the percentage removal of SP from the original skim milk is a measure of the efficiency of the process and can be used to compare the performance of different membrane systems. If there was no rejection of SP by an MF membrane, then in a $3 \times$ continuous bleed-and-feed process it would be expected that about $68.6 \%$ of the SP in the original skim milk would be removed in the MF permeate. There was a much lower $(P<0.05)$ percentage SP removal from skim milk for the SW polymeric membranes $(38.6 \%)$ compared with the ceramic membranes (Table 10) even though all processes were run at $3 \times$. Thus, the SW polymeric membranes had a much higher rejection of SP than the ceramic membranes, which is consistent with the SDS-PAGE data (Table 9) and with a previous report (Lawrence et al., 2008) indicating high rejection of $\beta$-LG using a similar SW polymeric membrane. The SP removal by the UTP system was higher $(P<$ 0.05) than that in the GP system (64.4 and $61.0 \%$, respectively) and was much closer to the theoretical SP removal rate of $68.6 \%$ for a $3 \times$ continuous bleed-andfeed system than the performance of the SW system. The UTP system contained polymeric beads in the permeate channel, and Dai et al. (1999) reported that pro-

Table 9. Mean $(n=3)$ relative proportions of casein to serum proteins for skim milk and retentates produced using ceramic uniform transmembrane pressure (UTP), ceramic graded permeability (GP), and polymeric spiral-wound (SW) membranes by densitometry analysis of the SDS-PAGE gels

\begin{tabular}{llcc}
\hline Sample & Membrane process & Casein & Serum proteins \\
\hline Milk & & 82.93 & 17.08 \\
Retentate & UTP & $93.93^{\mathrm{a}}$ & $6.07^{\mathrm{c}}$ \\
Retentate & GP & $93.14^{\mathrm{b}}$ & $6.86^{\mathrm{b}}$ \\
Retentate & SW & $90.03^{\mathrm{c}}$ & $9.97^{\mathrm{a}}$ \\
\hline
\end{tabular}

${ }^{\mathrm{a}-\mathrm{c}}$ Means in the same column not sharing a common superscript are different $(P<0.05)$. 
Table 10. Mean $(\mathrm{n}=3)$ serum protein removal for ceramic uniform transmembrane pressure (UTP), ceramic graded permeability (GP), and polymeric spiral-wound (SW) membranes

\begin{tabular}{lc}
\hline Membrane process & Serum protein removal (\%) \\
\hline UTP & $64.40^{\mathrm{a}}$ \\
GP & $61.04^{\mathrm{b}}$ \\
SW & $38.62^{\mathrm{c}}$ \\
\hline
\end{tabular}

${ }^{\mathrm{a}-\mathrm{c}}$ Means in the same column not sharing a common superscript are different $(P<0.05)$.

tein transmission into permeate was increased by beads packed on the permeate side of the membrane. The fact that both the UTP and GP systems resulted in SP removal slightly lower than the theoretical value could be because some SP are bound to the casein micelle, either due to heat denaturation during pasteurization (Sawyer, 1969) or due to chemical associations among some SP and casein in native casein micelle structure (Jost et al., 1999). Jost et al. (1999) reported that more lactoferrin, BSA, and immunoglobulin were retained in MF retentate than expected and that their retention by MF of unheated milk needed further investigation. Therefore, with a single pass through a $3 \times$ continuous bleed-and-feed system, it was possible to remove 60 to $65 \%$ of the SP in skim milk using ceramic UTP and GP membranes, whereas the SP removal by SW membranes used in this study was about 38 to $39 \%$ under the same conditions (Table 10). The percentage removal based on Kjeldahl and weights of products produced are consistent with the electrophoresis data for SP in the retentates compared with SP in the milk shown in Table 9. To produce a 60 to $65 \%$ SP reduced micellar casein concentrate with SW membranes would require multiple stages and diafiltration using either UF permeate (Nelson and Barbano, 2005) or water compared with a single-stage MF system for ceramic membranes.

The overall economics of the process would also be dependent on the weight $(\mathrm{kg})$ of SP removed per unit area of membrane per hour. Thus, the GP membrane removed a slightly lower percentage of the SP but the GP would remove more protein per hour because of the higher flux. All of these factors need to be considered in an economic comparison of the systems. For the future, high efficiency of removal of SP from skim milk and purity of the casein and SP fractions will be the key performance factors that will drive the economic performance of a system. These factors need to be balanced against the capital cost, membrane life, daily operational and cleaning costs of the system, and the selling price of the SP and micellar casein concentrate products of the filtration process.

\section{CONCLUSIONS}

There were differences in flux among ceramic UTP, ceramic GP, and polymeric SW MF membranes (54.08, 71.79 , and $16.21 \mathrm{~kg} / \mathrm{m}^{2}$ per hour, respectively) when processing skim milk at $50^{\circ} \mathrm{C}$ in a continuous bleedand-feed $3 \times$ process as well as differences in retentate and permeate composition. These differences in flux among the membranes would influence the amount of membrane surface area required to process a given volume of milk in a given time. Further work is needed to determine if these differences in flux are maintained over longer processing times. The true protein content of the MF permeate was higher for UTP and GP membranes than for SW membranes $(0.57,0.56$, and $0.38 \%$, respectively). Sodium-dodecyl-sulfate-PAGE for permeates revealed a greater casein proportion in GP and SW permeates compared with UTP permeate, with the highest passage of casein through the GP membrane. The slight cloudiness of permeates produced using the GP and SW systems may have been due to the presence of a small amount of casein, which may present an obstacle in their use in clear beverage applications when clarity is an important functional characteristic. More $\beta$-LG passed through the ceramic membranes than through the polymeric membrane. The efficiency of removal of SP in a continuous bleed-and-feed $3 \times$ process at $50^{\circ} \mathrm{C}$ was $64.40 \%$ for UTP, $61.04 \%$ for GP, and $38.62 \%$ for SW MF membranes. The polymeric SW membranes had a much higher rejection of SP than the ceramic membranes, which is consistent with the SDSPAGE data. For SW membranes to achieve a similar total SP removal from a given volume of skim milk as ceramic UTP and GP membranes, additional membrane surface area or diafiltration stages would have to be used in an SW MF system, which would add to the total cost of the processing with SW membranes.

\section{ACKNOWLEDGMENTS}

The authors thank the Northeast Dairy Foods Research Center and the Central and Eastern Europe Fellows Program for partial funding of this research. The technical assistance of Karen Wojciechowski, Jessica Mallozzi, Maureen Chapman, Chassidy Coon, and Bonnie Coffin from the Department of Food Science at Cornell University was greatly appreciated.

\section{REFERENCES}

Altmann, J., and S. Ripperger. 1997. Particle deposition and layer formation at the crossflow microfiltration. J. Membr. Sci. 124:119-128.

AOAC. 2000. Official Methods of Analysis. 17th ed. Association of Official Analytical Chemists, Gaithersburg, MD. 
Baruah, G. L., A. Nayak, and G. Belfort. 2006. Scale-up from laboratory microfiltration to a ceramic pilot plant: Design and performance. J. Membr. Sci. 274:56-63.

Brans, G., C. G. P. H. Schroën, R. G. M. van der Sman, and R. M. Boom. 2004. Membrane fractionation of milk: state of the art and challenges. J. Membr. Sci. 243:263-272.

Caron, A., D. Saint-Gelais, and Y. Pouliot. 1997. Coagulation of milk enriched with ultrafiltered or diafiltered microfiltered milk retentate powders. Int. Dairy J. 7:445-451.

Cheryan, M. 1998. Pages 31-69 and 237-291 in Ultrafiltration and Microfiltration Handbook. Technomic Publishing Company Inc., Lancaster, PA.

Dai, X.-P., R. G. Luo, and K. K. Sirkar. 1999. An integrated process for biomolecule isolation and purification. Biotechnol. Prog. 15:1095-1105.

Dai, X.-P., R. G. Luo, and K. K. Sirkar. 2000. Pressure and flux profiles in bead-filled ultrafiltration/microfiltration hollow fiber membrane modules. Biotechnol. Prog. 16:1044-1054.

Garcera D., and E. Toujas, inventors. 2002. Graded permeability macroporous support for crossflow filtration. Societe des Ceramiques Techniques, assignee. US Pat. No. US 6,375,014 B1.

Glantz, S. A., and B. K. Slinker. 2001. Multicollinearity and what to do about it. Pages 185-187 in Primer of Applied Regression and Analysis of Variance. 2nd ed. McGraw-Hill Inc., New York, NY.

Govindasamy-Lucey, S., J. J. Jaeggi, M. E. Johnson, T. Wang, and J. A. Lucey. 2007. Use of cold microfiltration retentates produced with polymeric membranes for standardization of milks for manufacture of pizza cheese. J. Dairy Sci. 90:4552-4568.

Grangeon, V., P. Lescoche, T. Fleischmann, and B. Ruschel, inventors. 2002. Cross-flow filter membrane and method to manufacture it. Technologies Avancees \& Membranes Industrialles (Societe Anonyme), assignee. US Pat. No. 6,499,606 B1.

Harland, H. A., S. T. Coulter, and R. Jenness. 1952. The effect of the various steps in the manufacture on the extent of serum protein denaturation in nonfat dry milk solids. J. Dairy Sci. 35:363-368.

Heath, C. A., G. Belfort, B. E. Hammer, S. D. Mirer, and J. M. Pimbley. 1990. Magnetic resonance imaging and modelling flow in hollow-fiber bioreactors. AIChE J. 36:547-558.

Holm S., R. Malmberg, and K. Svensson, inventors. 1990. Arrangement in membrane filter. Alfa-Laval Food Engineering AB, assignee. US Pat. No. 4,906,362.

Jost, R., R. Brandsma, and S. Rizvi. 1999. Protein composition of micellar casein obtained by cross-flow microfiltration of skimmed milk. Int. Dairy J. 9:389-390.

Jost, R., and P. Jelen. 1997. Cross-flow microfiltration-An extension of membrane processing of milk and whey. Implications of microfiltration on hygiene and identity of dairy products. IDF Bull. 320:9-15. Int. Dairy Fed., Brussels, Belgium.

Kaylegian, K. E., G. E. Houghton, J. M. Lynch, J. R. Fleming, and D. M. Barbano. 2006. Calibration of infrared milk analyzers: Modified milk versus producer milk. J. Dairy Sci. 89:2817-2832.
Lawrence, N. D., S. E. Kentish, A. J. O'Connor, A. R. Barber, and G. W. Stevens. 2008. Microfiltration of skim milk using polymeric membranes for casein manufacture. Separ. Purif. Tech. 60:237244

Ma, Y., C. Ryan, D. M. Barbano, D. M. Galton, M. A. Rudan, and K. J. Boor. 2000. Effects of somatic cell count on quality and shelf life of pasteurized fluid milk. J. Dairy Sci. 83:264-274.

Maubois, J.-L. 2002. Membrane microfiltration: A tool for a new approach in dairy technology. Aust. J. Dairy Technol. 57:92-96.

Morr, C. V., and E. Y. W. Ha. 1991. Off-flavors of whey protein concentrates: A literature review. Int. Dairy J. 1:1-11.

Nelson, B. K., and D. M. Barbano. 2005. A microfiltration process to maximize removal of serum proteins from skim milk before cheese making. J. Dairy Sci. 88:1891-1900.

Neocleous, M., D. M. Barbano, and M. A. Rudan. 2002a. Impact of low concentration factor microfiltration on milk component recovery and Cheddar cheese yield. J. Dairy Sci. 85:2415-2424.

Neocleous, M., D. M. Barbano, and M. A. Rudan. 2002b. Impact of low concentration factor microfiltration on composition and aging of Cheddar cheese. J. Dairy Sci. 85:2425-2437.

Pearce, R. J., S. C. Marshall, and J. A. Dunkerley. 1992. Reduction of lipids in whey protein concentrates by microfiltration-Effect on functional properties. Page 118-129 in Int. Dairy Fed., Special Issue 9201. IDF, Brussels, Belgium.

Quiñones, H. J., D. M. Barbano, and L. G. Philips. 1998. Influence of protein standardization by ultrafiltration on the viscosity, color, and sensory properties of 2 and 3.3\% milks. J. Dairy Sci. 81:884894

Riedl, K., B. Girard, and R. W. Lencki. 1998. Influence of membrane structure on fouling layer morphology during apple juice clarification. J. Membr. Sci. 139:155-166.

Saboya, L. V., and J.-L. Maubois. 2000. Current development of microfiltration technology in the dairy industry. Lait 80:541553.

Saint-Gelais, D., D. Roy, and P. Audet. 1998. Manufacture and composition of low fat Cheddar cheese from milk enriched with different protein concentrate powders. Food Res. Int. 31:137145 .

Sandblom, R. M., inventor. 1978. Filtering process. Alfa-Laval AB, assignee. US Pat. No. 4,105,547.

Sawyer, W. H. 1969. Complexes between $\beta$-lactoglobulin and $\kappa$-casein. A review. J. Dairy Sci. 52:1347-1355.

Verdi, R. J., D. M. Barbano, and M. E. Dellavalle. 1987. Variability in true protein, casein, nonprotein nitrogen, and proteolysis in high and low somatic cell count milks. J. Dairy Sci. 70:230-242.

Zeman, L. J. 1996. Part I. Scientific and manufacturing aspects of MF/UF membranes. Pages 17 to 23 in Microfiltration and Ultrafiltration: Principles and Applications. L. J. Zeman and A. L. Zydney, ed. Marcel Dekker Inc., New York, NY. 